\title{
Research Findings on Overactive Bladder
}

\author{
Phani B. Patra ${ }^{a} \quad$ Sayani Patra ${ }^{b}$ \\ aKing of Prussia; ${ }^{\mathrm{b}}$ Department of Pharmacology and Physiology, Drexel University College of Medicine, Philadelphia, Pa., USA
}

\begin{abstract}
Key Words
Ageing $\cdot$ Diabetes mellitus $•$ Bladder outlet obstruction • Spinal cord injury $\cdot$ Stroke $•$ Brain injury $\cdot$ Multiple sclerosis • Interstitial cystitis $\cdot$ Stress $\cdot$ Depression $\cdot$ Parkinson's disease
\end{abstract}

\begin{abstract}
Several physiopathologic conditions lead to the manifestation of overactive bladder (OAB). These conditions include ageing, diabetes mellitus, bladder outlet obstruction, spinal cord injury, stroke and brain injury, Parkinson's disease, multiple sclerosis, interstitial cystitis, stress and depression. This review has discussed research findings in human and animal studies conducted on the above conditions. Several structural and functional changes under these conditions have not only been observed in the lower urinary tract, but also in the brain and spinal cord. Significant changes were observed in the following areas: neurotransmitters, prostaglandins, nerve growth factor, Rho-kinase, interstitial cells of Cajal, and ion and transient receptor potential channels. Interestingly, alterations in these areas showed great variation in each of the conditions of the $O A B$, suggesting that the pathophysiology of the $O A B$ might be different in each condition of the disease. It is anticipated that this review will be helpful for further research on new and specific drug development against $\mathrm{OAB}$.

Copyright $\odot 2014$ S. Karger AG, Basel
\end{abstract}

\section{Introduction}

When talking about the overactive bladder (OAB), a question that comes into mind is what conditions are associated with the development of this physiopathologic state of the bladder. It has been observed that $\mathrm{OAB}$ is manifested during the following conditions: ageing, diabetes mellitus (DM), bladder outlet obstruction (BOO), spinal cord injury (SCI), stroke and brain injury, Parkinson's disease (PD), multiple sclerosis (MS), interstitial cystitis (IC), and stress and depression. The present review intends to discuss research findings from human and animal studies on OAB under these conditions. This would not only lead to an understanding of the pathophysiology of $\mathrm{OAB}$, but would also contribute to proper drug development against OAB. This review does not explore the scope of treatment options for OAB. However, an update on this topic is available in recent articles $[1,2]$. The terms OAB and detrusor overactivity (DO) were recommended by the International Continence Society for the pathophysiology of the lower urinary tract (LUT). According to the International Continence Society, OAB was defined as urgency, with or without urge incontinence, and usually with frequency and nocturia. DO was defined as an urodynamic observation characterized by involuntary detrusor contractions during the filling phase that may be spontaneous or provoked [3]. However, OAB may be more accurately defined as a hypersensitivity disorder rather than a syndrome characterized by urgency $[4,5]$. DO is the urodynamic hallmark of OAB. However, DO and OAB are not synonyms, they share therapeutic options and partially underlying physiopathological mechanisms $[6,7]$. There are 2 subtypes of $\mathrm{OAB}, \mathrm{OAB}$-dry (frequency and urgency without urgency

Phani B. Patra

521 Williams Road, Apt B9

King of Prussia, PA 19406 (USA)

E-Mail ppatra27705@yahoo.com 
incontinence) and $\mathrm{OAB}$-wet (frequency and urgency accompanied by urge incontinence) [8]. There is a sex-specific prevalence of OAB symptoms [9] that significantly impacts quality of life and social functioning [10].

The pathophysiology of OAB and DO is not well understood. However, this might be due to neurogenic and/ or myogenic factors $[11,12]$, alteration in the bladder afferent pathways [13], malfunctions of the urothelium and its signaling mechanism [14, 15], and moreover, due to abnormalities in the handling of afferent signals in the brain [16].

\section{Control of the LUT Functions}

LUT consists of the bladder and urethra innervated by sympathetic, parasympathetic and pudendal nerves. The major function of the LUT is to store urine in the bladder and to periodically evacuate urine at appropriate times. The neural circuitry that controls this process is complex; it involves pathways at many levels of the brain, spinal cord and the peripheral nervous system and is mediated by multiple neurotransmitters. This explains the high prevalence of urinary disturbances in neurological diseases [17-20]. Many of the neural circuits in the brain that control micturition exhibit switch-like patterns of activity that turn on and off in an all-or-none manner $[21,22]$.

\section{Bladder Filling}

During bladder filling, the parasympathetic function of the detrusor is inhibited, leading to the relaxation of the bladder with simultaneous contractions of the urethral sphincters (external and internal), preventing involuntary bladder emptying. This process is accomplished by norepinephrine, released from the sympathetic postganglionic (hypogastric) nerve. Norepinephrine acts on beta3-adrenoceptors (beta3-AR) in the detrusor, causing relaxation and enhancing bladder compliance, and also acts on alpha1-adenoceptors (alpha1-AR) in the bladder neck and urethra, enhancing bladder outlet resistance $[17,23,24]$.

\section{Bladder Evacuation}

When bladder volume reaches the micturition threshold, it activates the pontine micturition center to induce bladder contraction and relaxation of the urethra, leading to bladder emptying. Sensations of bladder fullness are conveyed to the spinal cord by the pelvic and hypogastric nerves, whereas the pudendal and hypogastric nerves carry the sensation from the bladder neck and urethra. Afferent fibers are primarily present in the trigone, though they are also distributed in the detrusor and urothelium. Afferent fibers consist of myelinated (A $\delta$ fiber which responds to passive distension) and unmyelinated (C fiber which responds to noxious chemicals and mechanical stimuli) axons. Bladder evacuation is predominantly accomplished by the parasympathetic nerve through the release of the excitatory neurotransmitter acetylcholine along with the co-transmitter ATP. Upon release, acetylcholine mainly acts on the detrusor via M3-muscarinic receptors (M3-MR) (and M2-MR during pathological situations), while ATP acts on P2X1-purine receptors (P2X1-PR) in the detrusor to initiate contraction $[13,17$, 23-26]. However, the maintenance of continence and a normal bladder micturition cycle involves a complex interaction of cholinergic, adrenergic, nitrergic and peptidergic systems that is currently not very well understood [27].

\section{Conditions Leading to the Development of OAB}

\section{Ageing}

$\mathrm{OAB}$ symptoms complex is one of the common causes of urinary incontinence (UI) in older people, which leads to the deterioration of bladder function [28, 29]. This might be due to weaker signals in the bladder control network of the brain [30] and sensory neuropathy as evidenced by enhanced urethral sensations [31].

Findings in Humans Ageing produced denervation in the bladder [32], with an increase in purinergic neurotransmission (PuNT) (increased release of ATP), decrease in cholinergic neurotransmission (ChNT) (decreased release of acetylcholine) [33], decrease in M3-MR in the detrusor, and an increase in M2-MR in the urothelium of both males and females [34]. However, a decrease in expression of P2X1-PR mRNA with age was noticed in the male detrusor [35].

Findings in Pigs There was an upregulation of mRNA levels of vascular endothelial growth inhibitor, death receptor 3 and nuclear factor kappa-B (NF-KB) in aged porcine detrusor [36].

Findings in Rats Ageing was associated with decreased bladder capacity and spontaneous bladder contractions in rats [37], reduction in MR in the detrusor $[38,39]$, a reduction in the contractile response of the detrusor to carbachol (CARB) [40], a shift in the contractile phenotype from M3-MR to M2-MR in males but not in females [41], an increased expression of P2Y4- 
PR and P2X3-PR [42, 43], an overexpression of the alpha-1D-AR [44], downregulation of urothelial nitric oxide synthase (NOS) [45] and endothelin receptors in the bladder [46]. Furthermore, ageing also produced a reduction in the number of spinal neurons expressing prostaglandin-21 (PG-21) androgen receptors, steroid receptor co-activator-1 (SRC-1), and phosphorylated form of C-AMP response element binding protein (pCREB) in aged males, while SRC-1 and pCREB expression was largely unchanged in aged females [47].

Findings in Guinea-Pigs Ageing produced DO, as demonstrated by short micturition interval, decreased bladder capacity, lower micturition pressure and spontaneous contractions during the filling phase [48]. Ageing also produced a functional loss of PuNT [49], reduced calcium sensitivity [50] and a significant decrease in acetylcholine esterase (AChE) positive neurons in the bladder [51].

Findings in Mice During ageing, central determinants of voiding initiation may become less sensitive to afferent input [52]. In aged mice, increased voiding frequency and enhanced low threshold afferent nerve activity was observed suggesting that ageing induces overactivity and hypersensitivity of the bladder. Moreover, ageing increased smooth muscle contractility and increased purinergic receptor sensitivity and raised $\mathrm{P} 2 \mathrm{X} 3$ receptor expression in the urothelium suggesting ageing evokes changes in purinergic signaling from the bladder [53]. There was a disruption of postsynaptic cholinergic pathway [54], decreased cholinergic response to bethanechol and enhanced purinergic response to ATP [55], partial loss of smooth muscle myosin heavy chain isoform 2 [56] and significant decrease in total antioxidant capacity and increased levels of lipid peroxides and inducible nitric oxide synthase (iNOS) in the bladder [57].

\section{Diabetes Mellitus (DM)}

Urinary bladder dysfunction is one of the most important clinical features in poorly controlled DM, which leads to diabetic neuropathy and cystopathy [58]. Diabetic cystopathy is characterized by incomplete emptying to urgency incontinence and time dependent manifestations of storage and emptying problems $[59,60]$. Patients with DM have a wide variety of voiding complaints that include DO, nocturia, incomplete emptying, urge and overflow incontinence, higher rates of $\mathrm{OAB}$ wet, and impairment in bladder sensation [60-63].

Findings in Humans DO due to DM involve both central and peripheral mechanisms [64] with an impairment in A delta as well as $\mathrm{C}$ fiber bladder afferent pathways

Overactive Bladder
[65] and an upregulation of Rho-kinase (ROK) signaling in the bladder [66].

Findings in Rats Experimental diabetes in rats with streptozotocin produced higher bladder capacity, higher compliance, increased residual urine volume, lower voiding efficiency [58, 67-69], dysfunctional urethra [67, 70, 71], upregulation of M3 and M2-MR in the detrusor and urothelium [72-74], increased responsiveness to CARB and acetylcholine due to increased MR [68, 75-77], potentiation of cholinergic motor transmission due to enhanced release of acetylcholine in the detrusor [78], upregulation of $\mathrm{P} 2 \mathrm{X} 2$ and $\mathrm{P} 2 \mathrm{X} 3-\mathrm{PR}$ in the urothelium [74], increased release of ATP in the urothelium [79], and upregulation of $\mathrm{P} 2 \mathrm{Y} 2, \mathrm{P} 2 \mathrm{Y} 4$ and $\mathrm{P} 2 \mathrm{X} 4-\mathrm{PR}$ in the detrusor $[42,74]$. However, diabetes may induce a plasticity of the nonadrenergic noncholinergic and purinergic ( $\mathrm{P} 2 \mathrm{X}$ type) mediated bladder contractile responses. The first one may be associated with diabetic neuropathic damage to bladder nerves, while impaired $\mathrm{P} 2 \mathrm{X}$ purinergic contractions might be associated with detrusor hypertrophy [80]. Furthermore, experimental DM also produced decreased sensitivity of the urethral muscle to adrenoceptor agonists [71], downregulation of alpha1a-AR in the bladder [81], augmentation in beta1-AR mediated relaxation of the detrusor [82], upregulation of ROK signaling $[83,84]$, a decreased number of interstitial cells of Cajal (ICC) [85], the presence of c-kit-positive ICC [86], decreased production of nerve growth factor (NGF) [58, 87-90], increased synthesis of PG-E2 and PG-F2alpha [91], decreased expression of cannabinoid receptors 1 and 2 [92], altered function and/or expression of $\mathrm{BKCa}$ and KATP channels [93], a higher ratio of ATP/nitric oxide (NO) [79], impairment in sodium/potassium-ATPase and calcium ATPase pump [94], and over activation of Poly (ADP-ribose) polymerase and NF-KB in the bladder [95]. 5-hydroxytryptamine (5-HT)-1A receptor agonism promoted periodic external urethral sphincter (EUS) activity, thereby improving voiding efficiency [67].

Findings in Rabbits Upregulation of PuNT and a decrease in ChNT in rabbit detrusor contrary to the findings in rat may be species dependent [96]. Exerimental diabetes produced a decrease in staining intensity of ICC in the bladder [97] and increased NOS binding sites in the bladder neck [98].

Findings in Mice Exerimental diabetes produced an increase in M2-MR mediated contractile function and a corresponding decrease in M3-MR [99]. Later, it was shown that the upregulation of M2 receptors inhibits the development of urinary bladder neuropathy in the hyperglycemic state [100]. Experimental diabetes also pro- 
duced upregulation of L-type voltage-operated calcium channels [101] and tumor necrosis factor alpha and ROK in the bladder [102].

\section{Bladder Outlet Obstruction (BOO)}

Physiological function of the bladder outlet is complex, and symptomatic consequences can result from outlet dysfunction [103]. BOO is much rarer in females than males [104]. In male patients, particularly in older age groups, $\mathrm{BOO}$ is comparatively common, usually as a consequence of benign prostatic hyperplasia $(\mathrm{BPH})$ that leads to OAB $[105,106]$. However, not all men with BPH develop lower urinary tract symptoms (LUTS). In addition, not all men with LUTS have $\mathrm{BPH}$ as the underlying cause [107].

Findings in Humans $\mathrm{BOO}$ in men produced significant changes in the bladder, including the emergence of purinergic, atropine-resistant contractions where ATP was a more potent contractile agonist [108, 109], increased P2X1-PR [110], an increased ATP/creatinine ratio [111], decreased expression of mucosal beta-3-AR [112], upregulation of alpha1-AR [113, 114], increased ROK signaling [115] and an upregulation of mucosal transient receptor potential (TRP) A1 channel [116]. BOO also produced increased urinary PGE2 [117], increased expression of iNOS in the urothelium [118], increased urinary NGF levels $[119,120]$ and decreased caveolin-1mRNA and protein in the detrusor of patients with BPH [121].

From the survey of research done on this topic, it is evident that different animal species (of either sex) with surgical induction of BOO have been used to study bladder function. Therefore in the following sections, research findings in animals have been categorized separately into males and females of their respective species.

Findings in Male Pigs $\mathrm{BOO}$ in Pigs gives a precisely defined bladder outlet resistence, closely resembling that of a human. In this animal models, BOO produced hypertrophy of the detrusor leading to the reduction in compliance. Voiding profiles showed a prolonged micturition time with high micturition pressure [122]. BOO also produced significant increase in the sensitivity of the detrusor to acetylcholine, reduction in response to intramural nerve stimulation affecting both cholinergic and non-cholinergic neurotransmission, partial denervation of the bladder and subsequent development of supersensitivity of the detrusor [123].

Findings in Male Rabbits $\mathrm{BOO}$ in male rabbits also seems to be an appropriate animal model with similar changes in bladder pathophysiology as those observed in men due to BPH [124]. BOO produced an increase in PuNT and a decrease in ChNT [125], enhanced ROK [126-128], elevated PGE2 and PGF2alpha [129, 130], upregulation of ET-1 receptors [131], upregulatin of vascular endothelial growth factor in the mucosa and angiopoietin 1 in the detrusor [132], decreased expression of caveolin 1, 2 and 3 in the hypertrophied detrusor [133], down regulation of calcium-activated potassium channels [134], impairment in protein kinase $C$ pathways [135], and bladder hypertrophy with involuntary bladder contractions [136]

Findings in Male Guinea-Pigs In this model, BOO produced DO, an increase in the population of ICC [137], a reduction in nerve density, total antioxidant capacity, glutathione and glutathione reductase [138], a reduction in sensory innervation and an increase in cholinergic innervation [139], enhanced ROK pathway [140], an increase in NO production [141], and upregulation of surface muscle ICC with M3-MR immunoreactivity in the bladder [142].

Findings in Male Rats Cystometric studies following $\mathrm{BOO}$ in rats revealed an increase in voiding frequency i.e. decrease in micturition interval (MI), a decrease in micturition volume, and an increase in non-voiding contraction (NVC) $[143,144]$. BOO also produced an increase in the expression of M2 and M3-MR and P2X3-PR in the urothelium, an increase in M3-MR in the detrusor [145], an increase in bladder beta2 and 3-AR [146, 147], an increase in NGF and TRPV1 [144, 148, 149], an increase of 5-HT2A receptor mRNA [150], upregulation of ROK pathway [151], an increase in angiotensin II type 1 receptors [144, 152], increased level of NO [153] and decreased Maxi-potassium channel activity in the bladder [154].

Findings in Male Mice BOO mediates both functional and structural changes in the mouse bladder. Six weeks of obstruction caused an increase in bladder capacity, DO and detrusor pressure [155]. BOO produced decrease in the expression of Caveolin-1 mRNA and protein content in the bladder smooth muscle [121]. Apart from this classical obstructed model of $\mathrm{BOO}$, transgenic male mice overexpressing aromatase have been used to investigate the molecular mechanism of BOO. These findings suggest the involvement of estrogen excess and/or imbalance of the androgen/estrogen ratio in the molecular pathogenetic mechanism of BOO [156]. Furthermore, induction of $\mathrm{BOO}$ with testosterone and $17 \beta$-estradiol produced voiding dysfunction after 2 and 4 months of hormone treatment and suggested to be a suitable model of BOO for better understanding of molecular mechanisms and for developing novel strategies to address $\mathrm{BPH}$ and $\mathrm{BOO}$ [157]. 
Findings in Female Pigs Obstructed bladder strips showed enhanced spontaneous phasic activity which might contribute to unstable myogenic bladder contractions observed in vivo [158] and 2-fold more sensitive to potassium depolarization [159].

Findings in Female Rabbits $\mathrm{BOO}$ resulted in a significant decrease in the activity of choline acetyltransferase [160].

Findings in Female Guinea Pigs In this model, BOO produced DO with $\mathrm{NVC}$, a reduction in micturition interval, an increase in micturition pressure, increased populations of ICC [161] and increase in c-kit positive ICC and spontaneous calcium waves with higher frequency in cultured ICC in the bladder [162].

Findings in Female Rats Apart from selecting male animals for $\mathrm{BOO}$, considerable studies have been done in female rat $\mathrm{BOO}$ models. BOO produced DO with NVCs, a decrease in micturition interval, and an increase in micturition pressure and bladder capacity after 2 to 6 weeks of BOO [163-167]. At the initial phase of BOO, decompensation of bladder activity was higher; however during the later phase, there was an increasing tendency of compensated bladders [167]. Moreover, there was an initial inflammatory response to the stress of the BOO as evidenced by a significant increase in mRNA levels of transforming growth factor $\beta$, connective tissue growth factor, hypoxia inducible factor $1 \alpha$, and platelet derived growth factor that eventually leads to fibrosis in the bladder [168]. It has been suggested that the occurance of DO and NVC following BOO might be due to the involvement of bladder mechanoreceptors, alpha1-AR, ATP, and glutamate receptors [164, 169-171]. BOO produced significant changes in the bladder that include the development of bladder hypertrophy with a thick urothelium [166], increased alpha-1d-AR [172], an increased population of ICC with enhanced P2X3-PR [165, 173], upregulation of M2-MR [41, 174], a decrease in M3-MR mediated contractility [175], an alteration in the sensitivity of detrusor to acetylcholine and substance-P [176], upregulation of ChNT and a marginal reduction in PuNT after 3 weeks of BOO [177] and a significant decrease in acetylcholine release following 3-6 months after BOO [178]. This discrepancy in ChNT between these 2 studies $[177,178]$ might be due to differences in the duration of BOO. Apart from these changes in the neurotransmitter system, BOO also produced other changes in the bladder, including increased NGF [179], increased expression of cold receptor TRPM8 in the epithelium and in the afferent neurons [166, 180], upregulation of EP4 receptors [181], increased iNOS, neuronal nitric oxide synthase (nNOS)

Overactive Bladder and endothelial NOS [165, 182, 183], higher expression of nNOS in the sacral 1 spinal cord in the females than males [184], upregulation of 5-HT1A and 5-HT2A receptors in the detrusor $[185,186]$, upregulation of connexin 43 [187], increased L-type calcium channels [188], enhanced the function of large conductance and small conductance calcium activated potassium channels in detrusor [189], increased expression of Aquaporin 2-3 channels [183], increased fibroblast growth factor in the urothelium [190], decreased expression of angiotensin II type 1 receptor [191], and functional alterations in bladder afferent pathways [192]. Moreover, BOO also produced downregulation of TWIK-related arachidonic acid-activated potassium channels [193] and an irreversible decrease of glycinergic activity in the spinal cord [194]. It has been observed that EP1 receptor was involved in the initiation of micturition in BOO rats [195].

Findings in Female Mice $\mathrm{BOO}$ produced increased NVC, threshold pressure, micturition pressure, bladder capacity and residual urine volume [196, 197]. BOO also produced enhanced ChNT, reduced PuNT and an increase in ROK signalling [198], induction in cyclooxygenase (COX)-2 [199] and iNOS expression [200], upregulation of protein kinase pathway [201], upregulation of the hypoxia inducible factor-1 pathway [202] and downregulation of stretch-dependant potassium channels called TREK-1 in the bladder [203]. It has been observed that macrophage migration inhibitory factor is involved in the sequence of events leading to detrusor muscle loss and fibrosis following obstruction [204]. Furthermore, it has been observed that EP1 was not involved in controling micturition of BOO mice [205] contrary to the finding in rat [195] suggesting a species difference in the involvement of PG receptors in bladder function following obstruction.

\section{Spinal Cord Injury (SCI)}

SCI produces bladder dysfunction, leading to the impairment of storage and voiding functions (i.e. ranging from UI to complete loss of the capacity to empty the bladder) [206]. Functionally, the bladder is initially areflexic (with complete urinary retention), but then becomes hyperreflexic due to the emergence of a spinal micturition reflex pathway. However, voiding is commonly inefficient due to simultaneous contractions of the bladder and urethral sphincter (detrusor sphincter dyssynergia) $[207,208]$. 


\section{Findings in Humans}

Recent observations have suggested the emergence of two independent excitatory pudendal-to-bladder reflex pathways following SCI [209]. Several notable changes have been observed following SCI, including an upregulation of M2-MR [210], P2X2 and P2X3-PR in the bladder [211, 212], enhanced release of ATP in the damaged spinal tissue [213], increased TRPV1 immunoreactivity in the urothelium [214, 215], increased expression of iNOS in the urothelium [216], increased NGF in urine [120] and abnormalities in urothelial expression in epidermal growth factor (EGF) receptors [217].

\section{Findings in Rats}

This animal model closely resembles the clinical conditions of SCI. The relative low cost of this animal model and the easy maintenance makes it a valuable tool to study such a condition [218]. SCI in rats displayed NVC during bladder filling, resulting in an increased bladder afferent nerve firing [219]. At the initial phase of SCI, there might be a failure in ChNT, as revealed from a decrease in the vesicular ACh transporter-positive fibers in the bladder [220]. Furthermore, there was a higher expression of $\alpha 1 \mathrm{~d}-\mathrm{AR}$ in the detrusor [221], predominance of M2-MR in the detrusor and urothelium [222, 223], upregulation of PuNT in the bladder and an enhanced release of ATP in the spinal cord [224-227] and involvement of the P2X3/P2X2/3-PR on bladder afferent nerves in regulating sensory activity and NVCs in the bladder [228]. Other notable changes in the bladder following SCI include an impairment in urothelial function [229], upregulation of ET-1 receptors [230], increased release of PGE2 (where the urothelium partly contributes to this increase) [231], increased expression of connexin 43 and 26 in the urothelium [232], increased levels of NGF [233], upregulation of the kinin B1 and B2 receptors [234], up-regulation of TRPA1 [235], involvement of TRPV1 in producing neurogenic DO [236], decreased population of ICC [237], downregulation of voltagegated potassium channels [238], and an upregulation of signal-regulated kinase 1 and 2 pathways [239]. Several notable changes have also been observed in the spinal cord, including the sprouting of the afferent fibers with the expression of substance P (SP) [240, 241], increased levels of NGF [233], higher expression of NOS [242], upregulation of EGF receptors [243], increased number of Fos immunoreactive cells [244], expression of pituitary adenylate cyclase activating peptide [245], increase in the excitatory amino acid glutamate, and the inhibitory amino acids glycine and taurine [246], hypofunction of gamma amino butyric acid (GABA)-ergic mechanisms which might be responsible, at least in part, for the development of detrusor sphincter dyssynergia after SCI [247]. It has been reported that activation of 5-HT1A receptors that produce relaxation of the EUS improve voiding efficiency and LUT function following SCI [248-250].

\section{Findings in Cats}

Capsaicin-sensitive $\mathrm{C}$ fiber bladder afferents contribute to bladder hyperactivity and play an essential role in triggering automatic micturition in chronic SCI cats [251]. Circuitry for both the excitatory and inhibitory pudendal afferent nerves to bladder reflexes undergoes a marked reorganization after SCI [252]. Chronic SCI produces an expression of vasoactive intestinal peptide immunoreactivity in primary afferent axons in the lumbosacral spinal cord [245] and emergence of 2 populations of bladder afferent $\mathrm{C}$-fibers (chemosensitive and mechanosensitive) [253]. Activation of 5-HT1A receptors produce an action on inter neuronal pathways in the spinal cord or on the C-fiber afferent limb of the spinal micturition reflex and not on bladder smooth muscle or the efferent limb of the reflex pathway to inhibit DO from SCI [254].

\section{Findings in Rabbits}

In this animal model, no micturition reflex, EUS activity, or hind-limb spasticity were observed and the flaccid state continued for 4 weeks. It is suggested that a segmental micturition reflex pathway exists initially in the rabbit sacral cord, because reappearance of the micturition reflex was extremely quick (1-2 days) compared to that of cats (2-3 weeks) [255]. ChNT increased to $75 \%$ whereas the PuNT decreased to $25 \%$ in the bladder following chronic SCI suggesting the shifting of neurotransmission to a cholinergic dominance [256].

\section{Findings in Mice}

Aquaporin-4 water channels plays a protective role after contusion following SCI by facilitating the clearance of excess water to reduce spinal cord edema, and that targeting edema after SCI may be a novel therapeutic strategy [257].

\section{Stroke and Brain Injury}

UI with various patterns of detrusor contractility is frequently observed in patients following stroke, cerebrovascular accident, and traumatic brain injury [258, 259]. 


\section{Findings in Rats}

Cystometric studies in the rat, following experimental cerebral infarction by occlusion of the middle cerebral artery, revealed DO with a decrease in bladder capacity, micturition volume, micturition interval and an increase in residual urine volume [260-263]. These effects are seen in the bladder, spinal cord and brain. In the bladder, there was an up-regulation of MR [262] and nNOS [264]. In the spinal cord, there was an upregulation of nNOS [264]. In the brain, there was a downregulation in the kappa opioidergic mechanism, decrease in glutamate, and glycine levels [265, 266], a downregulation of AChE [267], an alteration of the dopaminergic-glutamatergic interaction [268], a change in the GABA-ergic mechanism [269] and an increase in COX-2 and PG-E synthase (i.e. activation of the arachidonic acid cascade) $[261,270]$.

\section{Parkinson's Disease (PD)}

PD is an extrapyramidal neurological disorder due to the degeneration of the nigrostriatal dopaminergic pathways that produces dysfunction of the LUT with symptoms of urgency, frequency, nocturia and urge incontinence as the disease progresses [271-273]. There is a greater incidence of PD in men than in women [274].

\section{Findings in Rats}

The 6-Hydroxydopamine (6-OHDA) model is a widely used animal model of PD [275]. Male rats were observed to be more susceptible to the 6-OHDA treatment than females [276]. The 6-OHDA model produced DO, as reflected by higher micturition frequency (i.e. decreased MI, bladder capacity, micturition volume, bladder compliance and increase in maximal micturition pressure [277-279], which might be due to dysfunction of GABAergic regulation underlying the micturition reflex [279] and enhanced supra spinal adenosine A2A receptors [280].

\section{Multiple Sclerosis (MS)}

MS is an inflammatory disease that leads to disseminated lesions of the central nervous system, resulting in both somatomotor and autonomic disturbances [281]. Most MS patients suffer from DO, UI, detrusor sphincter dyssnergia, and difficulty in emptying the bladder [282, 283].

\section{Findings in Humans}

Bladder biopsies of MS patients revealed an increase in P2X3-immunoreactive nerve fibers in the suburothelium [211], an increase in urothelial TRPV1 [215], a greater density of calcitonin gene-related peptide and SP positive nerve fibers [284) and presence of ICC in the upper lamina propria with a shift towards a fibroblast phenotype [285]. It has been observed that cannabidiol, a non-psychoactive cannabinoid, reduced ACh-induced contractions in the bladder, suggesting the efficacy of cannabis medicines in reducing UI episodes in patients with MS [286].

\section{Findings in Rats}

Induction of experimental autoimmune encephalomyelitis in rats, a model of MS produced bladder dysfunction as revealed from the increase in bladder size with detrusor hyperactivity [287, 288].

\section{Findings in Mice}

Experimental autoimmune encephalomyelitis model in mice produced enhanced expression of connective tissue growth factor and increased growth of connective tissue in the bladder [289]. Apart from the experimental autoimmune encephalomyelitis model of MS, infection with Semliki Forest Virus in mice has also been proposed as another animal model for MS. In this model, there was an increase in PuNT in the bladder without any change in ChNT [290]. Despite these few studies, it is needless to say that further research needs to be done to evaluate LUT function in animal models of MS.

\section{Interstitial Cystitis (IC)}

IC is defined as a chronic inflammatory multifactorial bladder syndrome of unknown etiology [291]. UI due to IC is more prevalent in women, affecting 1 in every 4 to 5 women and 1 in every 20 men [292], suggesting the role of female sex hormones in IC [293].

\section{Findings in Humans}

Significant findings in the bladder of IC patients include an upregulation of purinergic signaling [294], increased expression of P2X-PR and ATP release in the urothelium [295, 296], significant upregulation of M2MR, P2X1 and P2X2-PR in the detrusor [297], increased urinary NGF levels [298-300], loss of PGE2 from the 
urothelial cells [301], enhanced expression of SP receptors in the detrusor [302], enhanced levels of bradykinin in the bladder [303], increased TRPM8 immunoreactivity [304], increased expression of TRPV1, 2 and 3, TRPM2 and NGF [305], increased expression of iNOS in the urothelium [306] and high levels of NO in the bladder [307].

\section{Findings in Cats}

Feline cystitis (FC) is used as an animal model for human IC [308]. Research findings from FC have shown increased ATP and decreased P2X1 and P2Y2-PRs in the urothelium, decreased P2X1-PRs in the detrusor [309, $310]$ and increased expression of iNOS in the detrusor and urothelium [311].

\section{Findings in Rats}

Apart from the FC model, cystitis was also induced in rats by cyclophosphamide treatment, which produced IC-like inflammatory changes [312]. Cystometric studies in cyclophosphamide treated rats have revealed a higher rate $(83 \%)$ of DO with lower bladder capacity, lower compliance, and decreased micturition interval [313]. Cyclophosphamide treatment produced abnormalities in bladder function following downregulation of pharmacologically relevant MR and PR in the bladder [314, 315], increased expression and/or function of P2X-PR in both the pelvic and lumbar splanchnic pathways [316], upregulation of iNOS in the detrusor and urothelium [317], upregulation of BK-B1 receptors in the urothelium [318], upregulation of NOS expression in the neuronal voiding centers [319], upregulation of NGF in the detrusor and urothelium [317, 320], increased expression of COX-2 and EP4 in the bladder [321, 322], activation of TRPA1 in the bladder [323] and involvement of transforming growth factor-beta isoforms (1, 2 and 3$)$ and their receptors in the bladder in cyclophosphamide mediated cystitis [324], increased FOS immunoreactive cells in the spinal cord [325], a higher concentration of PGE2 in the spinal cord [326], increased expression of COX-2 and EP4 in the spinal cord [322], increased urinary levels of interleukin-1 $\beta$ and interleukin-17 [314]. Female rats treated with cyclophosphamide had significantly higher levels of NO2-/NO3- in urine when compared to male rats, suggesting the role of $\mathrm{NO}$ in the manifestation of IC predominantly found in females [327].

\section{Findings in Mice}

Exerimental cystitis produced significant upregulation of P2X7-PR [328], activation of $\mathrm{Ca}_{\mathrm{v}} 3.2$ channels, one of the T-type calcium channels [329], and distention-induced ATP release in the bladder [330].

\section{Findings in Guinea-Pigs}

In connection to the increased purinergic signaling and inflammatory mediators in the bladder of IC patients, it has been observed that histamine, bradykinin, and SP potentiated PuNT in the guinea-pig bladder $[331,332]$.

\section{Stress and Depression}

Studies have revealed an association between depression and OAB symptoms [333] and women are more likely than men to have symptoms of depression [334]. These observations are further correlated with the findings that occupational stress and a history of depression are risk factors for the development of OAB in women [335-337], where corticotropin releasing factor (CRF) [338] and central monoamines might be involved [339].

\section{Findings in Rats}

Exposure of social stress in rats induced bladder dysfunction resembling $\mathrm{OAB}$ due to the upregulation of $\mathrm{CRF}$ in the Barrington's nucleus in the brain [340]. It has also been reported that psychological stress in rats produced an increase in mictution frequency with a simultaneous increase in mast cells of the bladder [341]. Role of CRF in producing DO is strengthened by the fact that CRF itself stimulated micturition in normal [342] and cyclophosphamide treated rats [343]. Interestingly, it has been observed that CRF signaling in rats during stress is sex dependent where females are more sensitive to low levels of CRF [344]. However, other than social stress, cold stress and repeated variate stress also produced DO in rodents [345, 346]. Moreover, rats treated with clomipramine in neonatal conditions developed depression in adult condition with symptoms of OAB possibly through altered serotonin function in brain [347].

\section{Conclusion}

Studies cited in this review have shown several structural and functional changes in not only the LUT but also in the brain and spinal cord under different physiopathologic conditions of OAB ( table 1). Alterations have been observed in the human and animal bladders in the following areas: neurotransmitter systems such as the cholinergic, purinergic, adrenergic, serotonergic, glycinergic, GABA-ergic, and nitrergic systems, as well as 
Table 1. Summary of the major findings under different conditions of $\mathrm{OAB}$ in humans and animals

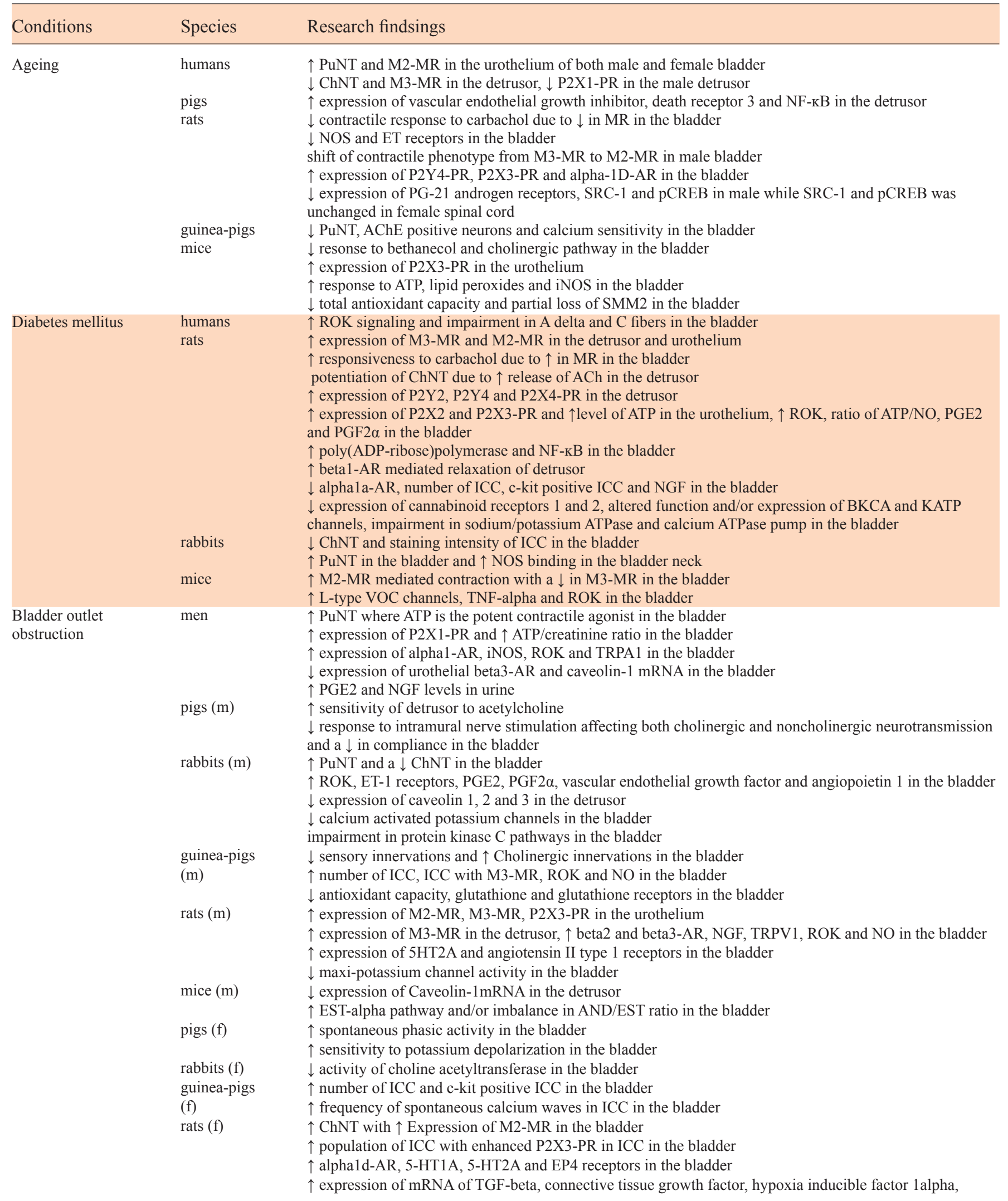


Table 1. (continued)

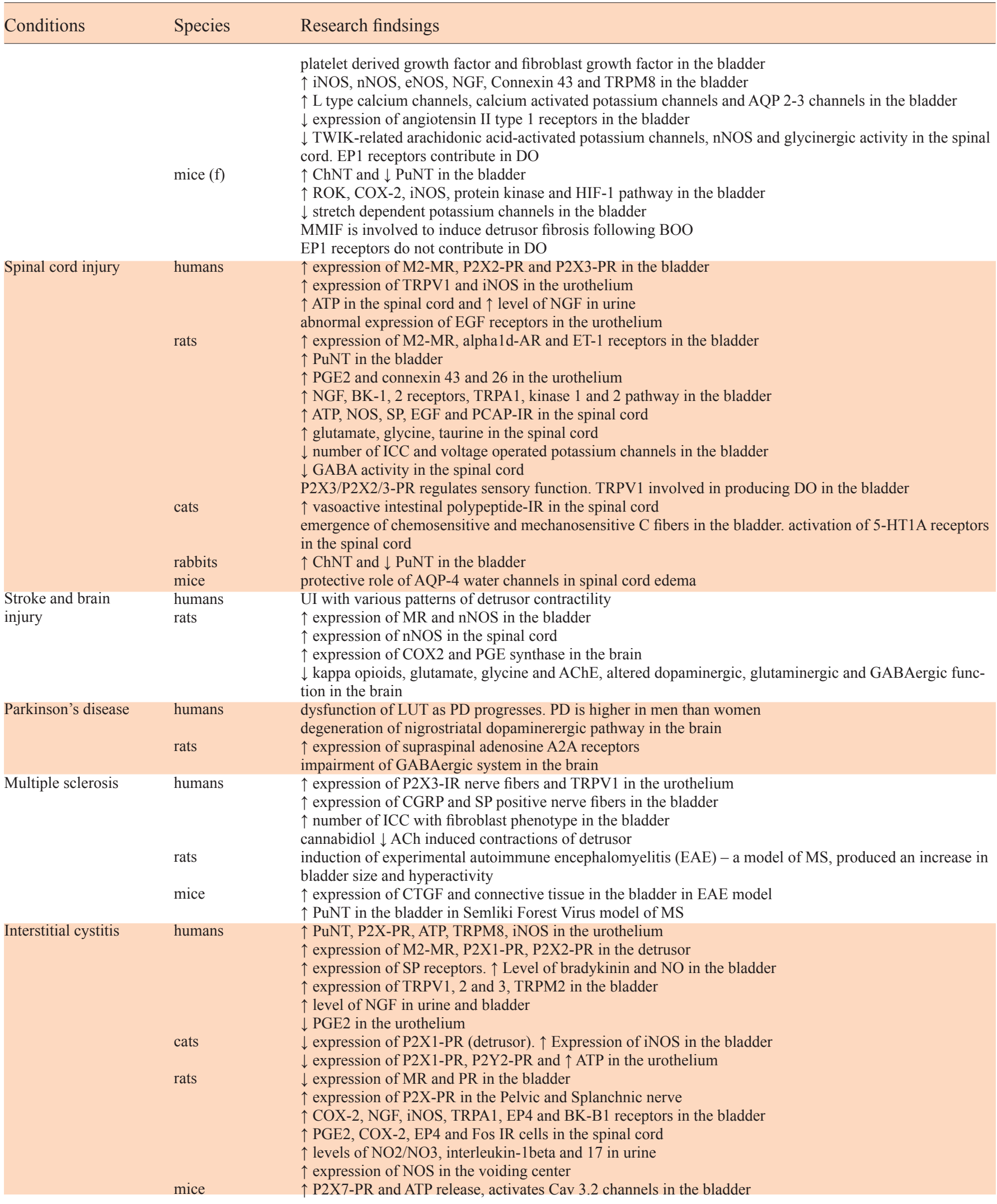


Table 1. (continued)

\begin{tabular}{lll}
\hline Conditions & Species & Research findsings \\
\hline $\begin{array}{l}\text { Stress and depres- } \\
\text { sion }\end{array}$ & $\begin{array}{l}\text { guinea-pigs } \\
\text { humans } \\
\text { rats }\end{array}$ & $\begin{array}{l}\text { potentiation of PuNT by histamine, bradykinin and SP in the bladder } \\
\text { stress and depression are risk factors for OAB in women } \\
\end{array}$ \\
& $\begin{array}{l}\uparrow \text { CRF in Barrington's nucleus in the brain. } \uparrow \text { Mast cells in the bladder } \\
\text { sex difference in CRF sensitivity which is higher in female than male }\end{array}$ \\
\hline
\end{tabular}

$\uparrow=$ Increase; $\downarrow=$ decrease; $\mathrm{M}=$ male; $\mathrm{F}=$ female; $\mathrm{MR}=$ muscaric receptor; $\mathrm{PR}=$ purine receptor; $\mathrm{NF}-\mathrm{KB}=$ nuclear factor kappa-B; ET = endothelin; $\mathrm{SRC}-1$ = steroid receptor co-activator-1; $\mathrm{pCREB}=$ phosphorylated form of C-AMP response element binding protein; AChE = acetylcholine esterase; $\mathrm{SMM} 2=$ smooth muscle myosin heavy chain isoform $2 ; \mathrm{VOC}=$ voltage operated calcium; $\mathrm{TNF}=$ tumor necrosis factor; $\mathrm{EST}=\mathrm{estrogen} ; \mathrm{AND}=$ androgen; $\mathrm{TGF}=$ transforming growth factor; HIF = hypoxia inducible factor; MMIF = macrophage migration inhibitory factor; EGF = epidermal growth factor; BK-1, 2 = bradykinin 1 and 2; PCAP = pituitary adenylate cyclase-activating peptide; $\mathrm{CGRP}=$ calcitonin gene related peptide; $\mathrm{SP}=$ substance $\mathrm{P} ; \mathrm{CTGF}=$ connective tissue growth factor.

in other areas such as PG, NGF, ROK, ICC, TRP and ion channels. M2-MR was increased in ageing, DM, BOO, SCI and IC. PuNT was increased in ageing, BOO, SCI, MS, DM and IC. ROK was increased in BOO and DM. TRP channel activity was enhanced in BOO, SCI, MS and IC. Furthermore, ICC was increased in BOO and MS. As these areas [25, 348-355] play crucial roles in the central and peripheral regulation of LUT functions, further research should be conducted in order to find better therapeutic targets against OAB. However, apart from these areas, cannabinoids seems to be a promising area for future drug development research on $\mathrm{OAB}$ due to their involvement in controlling LUT function in animals and humans $[356,357]$ especially, in patients with MS [286, 358-360], BOO [361], rat models of DM [92] and mouse models of cystitis [362, 363]. Interestingly, there was a lack of similar alterations between human and animal studies with respect to the structural and functional changes in the LUT due to the conditions of OAB. From the perspective of human studies, this might be due to the presence of different disease conditions, and in the case of animal studies, this might be due to either the use of different animal models [364, 365] or a sex difference that affects the physiology and pharmacology of the LUT [9, 366-368]. However, the existence of different mechanisms in the pathophysiology of the LUT cannot be ruled out for each of the conditions of OAB. In fact, this would be justified by the fact that patients with different conditions of OAB may appear to have similar symptoms, but in reality, the underlying mechanisms may be diverse $[369,370]$. Therefore, the same treatment is unlikely to be effective for OAB since different conditions require different approaches for optimal manage- ment $[371,372]$. It is anticipated that this review would be helpful for future research on $\mathrm{OAB}$ with a prospect of improved and more specific drug development in order to find satisfactory relief for OAB patients. 


\section{References}

1 Athanasopoulos A, Cruz F: The medical treatment of overactive bladder, including current and future treatments. Expert Opin Pharmacother 2011;12:1041-1055.

2 Yamaguchi O: Latest treatment for lower urinary tract dysfunction: therapeutic agents and mechanism of action. Int J Urol 2013;20:2839.

3 Abrams P, Cardozo L, Fall M, Griffiths D, Rosier P, Ulmsten Ulf, van Kerrebroeck P, Victor A, Wein A: The standarisation of terminology of lower urinary tract function: report from the standardization Sub-committee of the International Continent Society. Neurourol Urodyn 2002;21:167-178.

4 Yamaguchi O, Honda K, Nomiya M, Shishido K, Kakizaki H, Tanaka H, Yamanishi T, Homma Y, Takeda M, Araki I, Obara K, Nishizawa O, Igawa Y, Goto M, Yokoyama O, Seki N, Takei M, Yoshida M: Defining overactive bladder as hypersensitivity. Neurourol Urodyn 2007;26:904-907.

5 Lee SR, Kim HJ, Kim A, Kim JH: Overactive bladder is not only overactive but also hypersensitive. Urology 2010;75:1053-1059.

6 Antunes-Lopes T, Carvalho-Barros S, Cruz $\mathrm{CD}$, Cruz F, Martins-Silva C: Biomarkers in overactive bladder: a new objective and noninvasive tool? Adv Urol 2011;2011:382431.

7 Cerruto MA, Asimakopoulos AD, Artibani W, Del Popolo G, La Martina M, Carone R, Finazzi-Agrò E: Insight into new potential targets for the treatment of overactive bladder and detrusor overactivity. Urol Int 2012; $89: 1-8$.

8 Anger JT, Le TX, Nissim HA, Rogo-Gupta L, Rashid R, Behniwal A, Smith AL, Litwin MS, Rodriguez LV, Wein AJ, Maliski SL: How dry is "OAB-dry"? Perspectives from patients and physician experts. J Urol 2012; 188:1811-1815.

9 Patra PB and Patra S: Sex differences in the physiology and pharmacology of the lower urinary tract. Curr Urol 2012;6:179-188.

10 Arnold J, McLeod N, Thani-Gasalam R, Rashid P: Overactive bladder syndrome Management and treatment options. Aust Fam Physician 2012;41:878-883.

11 de Groat WC: A neurologic basis for the overactive bladder. Urology 1997;50(suppl 6A):36-52.

12 Brading AF: A myogenic basis for the overactive bladder. Urology 1997;50(suppl 6A):57-67.

13 de Groat WC, Yoshimura N: Afferent nerve regulation of bladder function in health and disease. Handb Exp Pharmacol 2009; 194:91138.

14 Birder L, Andersson KE: Urothelial signaling. Physiol Rev 2013;93:653-680.

15 de Groat WC: Highlights in basic autonomic neuroscience: contribution of the urothelium to sensory mechanisms in the urinary bladder. Auton Neurosci 2013;177:67-71.
16 Griffiths D: Imaging bladder sensations. Neurourol Urodyn 2007;26:899-903.

17 Fowler CJ, Griffiths D, de Groat WC: The neural control of micturition. Nat Rev Neurosci 2008;9:453-466.

18 Beckel JM, Holstage G: Neuroanatomy of the lower urinary Tract; In Andersson KE, Michel MC (eds): Urinary Tract, Handbook of Experimental Pharmacology 202. Springer-Verlag Berlin Heidelberg 2011, pp99-116.

19 Beckel JM, Holstage G: Neurophysiology of the Lower Urinary Tract; In Andersson KE, Michel MC (eds): Urinary Tract, Handbook of Experimental Pharmacology 202, Springer-Verlag Berlin Heidelberg 2011, pp149-169.

20 Panicker JN, De Sèze M, Fowler CJ: Neurogenic lower urinary tract dysfunction. Handb Clin Neurol 2013;110:209-220.

21 de Groat WC, Wickens C: Organization of the neural switching circuitry underlying reflex micturition. Acta Physiol (Oxf) 2013; 207:66-84.

22 Griffiths DJ, Fowler CJ: The micturition switch and its forebrain influences. Acta Physiol (Oxf) 2013;207:93-109.

23 Ochodnicky P, Uvelius B, Andersson KE, Michel MC: Autonomic nervous control of the urinary bladder. Acta Physiol (Oxf) 2013; 207:16-33.

24 Michel MC, Barendrecht MM: Physiological and pathological regulation of the autonomic control of urinary bladder contractility. Pharmacol Ther 2008;117:297-312.

25 Andersson KE, Arner A: Urinary Bladder Contraction and Relaxation: Physiology and Pathophysiology. Physiol Rev 2004;84:935986.

26 Burnstock G: Purinergic signalling in the lower urinary tract. Acta Physiol (Oxf) 2013; 207:40-52.

27 Sellers DJ, Chess-Williams R: Muscarinic agonists and antagonists: effects on the urinary bladder. Handb Exp Pharmacol 2012; 208:375-400.

28 Wagg AS, Cardozo L, Chapple C, de Ridder D, Kelleher C, Kirby M, Milsom I, Vierhout $\mathrm{M}$ : Overactive bladder syndrome in older people. BJU Int 2007;99:502-509.

29 Valentini AF, Robain G, Marti BG: Urodynamics in women from menopause to oldest age: what motive? What diagnosis? Int Braz J Urol 2011;37:100-107.

30 Griffiths DJ, Tadic SD, Schaefer W, Resnick NM: Cerebral control of the lower urinary tract: how age-related changes might predispose to urge incontinence. Neuroimage 2009; 47:981-986.

31 Kenton K, Lowenstein L, Simmons J, Brubaker L: Aging and overactive bladder may be associated with loss of urethral sensation in women. Neurourol Urodyn 2007;26:981984.
32 Fry $\mathrm{CH}$, Bayliss M, Young JS, Hussain M: Influence of age and bladder dysfunction on the contractile properties of isolated human detrusor smooth muscle. BJU Int 2011; 108:E91-E96.

33 Yoshida M, Miyamae K, Iwashita H, Otani $\mathrm{M}$, Inadome A: Management of detrusor dysfunction in the elderly: changes in acetylcholine and adenosine triphosphate release during aging. Urology 2004;63:17-23.

34 Mansfield KJ, Liu L, Mitchelson FJ, Moore $\mathrm{KH}$, Millard RJ, Burcher E: Muscarinic receptor subtypes in human bladder detrusor and mucosa, studied by radioligand binding and quantitative competitive RT-PCR: changes in ageing. Br J Pharmacol 2005; 144:1089-1099.

35 Chua WC, Liu L, Mansfield KJ, Vaux KJ, Moore KH, Millard RJ, Burcher E: Age related changes of $\mathrm{P} 2 \mathrm{X} 1$ receptor $\mathrm{mRNA}$ in the bladder detrusor from men with and without bladder outlet obstruction. Exptl Gerontol 2007;42:686-692.

36 Wang M, Zhang N, Wang W, Wang B, Xu Z, Yang Y: Expression and function of vascular endothelial growth inhibitor in aged porcine bladder detrusor muscle cells. Biogerontology 2013;14:543-556.

37 Zhao W, Aboushwareba T, Turner C, Mathis C, Bennett C, Sonntag WE, Andersson KE, Christ G: Impaired bladder function in aging male rats. J Urol 2010;184:378-385.

38 Pagala MK, Tetsoti L, Nagpal D, Wise GJ: Aging effects on contractility of longitudinal and circular detrusor and trigone of rat bladder. J Urol 2001;166:721-727.

39 Schneider T, Hein P, Michel-Reher MB, Michel MC: Effects of ageing on muscarinic receptor subtypes and function in rat urinary bladder. Naunyn Schmiedebergs Arch Pharmacol 2005;372:71-78.

40 Owen SJ, Rose'Meyer RB, Massa HM: Dietary phytoestrogens maintain contractile responses to carbachol with age in the female rat isolated bladder. Life Sci 2011;89:213220

41 Ruggieri MR Sr, Braverman AS: Regulation of bladder muscarinic receptor subtypes by experimental pathologies. Auton Autacoid Pharmacol 2006;26:311-325.

42 Suadicani SO, Urban-Maldonado M, Tar MT, Melman A, Spray DC: Effects of ageing and streptozotocin-induced diabetes on connexin43 and P2 purinoceptor expression in the rat corpora cavernosa and urinary bladder. BJU Int 2009;103:1686-1693.

43 Studeny S, Torabi A, Vizzard MA: P2X2 and $\mathrm{P} 2 \mathrm{X} 3$ receptor expression in postnatal and adult rat urinary bladder and lumbosacral spinal cord. Am J Physiol Regul Integr Comp Physiol 2005;289:R1155-R1168.

44 Dmitrieva N, Zhang G, Nagabukuro H: Increased alpha1D adrenergic receptor activity and protein expression in the urinary bladder of aged rats. World J Urol 2008;26:649-655. 
45 Lluel P, Palea S, Ribiere P, Barras M, Teillet L, Corman B: Increased adrenergic contractility and decreased mRNA expression of NOS III in aging rat urinary bladders. Fundam Clin Pharmacol 2003;17:633-641.

46 Afiatpour P, Latifpour J, Takahashi W, Yono M, Foster HE Jr, Ikeda K, Pouresmail M, Weiss RM: Developmental changes in the functional, biochemical and molecular properties of rat bladder endothelin receptors. Naunyn Schmiedebergs Arch Pharmacol 2003;367:462-472.

47 Ranson RN, Connelly JH, Santer RM, Watson AH: Nuclear expression of PG-21, SRC1 , and pCREB in regions of the lumbosacral spinal cord involved in pelvic innervation in young adult and aged rats. Anat Cell Biol 2012;45:241-258.

48 Gomez-Pinilla PJ, Gomez MF, Hedlund P, Sward K, Hellstrand P, Camello PJ, Pozo MJ, Andersson KE: Effect of melatonin on age associated changes in guinea-pig bladder function. J Urol 2007;177:1558-1561.

49 Gomez-Pinilla PJ, Pozo MJ, Camello PJ: Aging impairs neurogenic contraction in guinea pig urinary bladder: role of oxidative stress and melatonin. Am J Physiol Regul Integr Comp Physiol 2007;293:R793-R803.

50 Gomez-Pinilla PJ, Gomez MF, Swärd K, Hedlund P, Hellstrand P, Camello PJ, Andersson KE, Pozo MJ: Melatonin restores impaired contractility in aged guinea pig urinary bladder. J Pineal Res 2008;44:416-425.

51 Mizuno MS, Pompeu E, Castelucci P, Liberti EA: Age-related changes in urinary bladder intramural neurons. Int J Dev Neurosci 2007 25:141-148.

52 Smith PP, DeAngelis A, Kuchel GA: Detrusor expulsive strength is preserved, but responsiveness to bladder filling and urinary sensitivity is diminished in the aging mouse. Am J Physiol Regul Integr Comp Physiol 2012;302:R577-586.

53 Daly DM, Nocchi L, Liaskos M, McKay MG, Chapple C, Grundy D: Age-related changes in afferent pathways and urothelial function in the mouse bladder. J Physiol 2014; 592(Pt 3): $537-549$

54 Lai HH, Boone TB, Thompson TC, Smith CP, Somogyi GT: Using caveolin-1 knockout mouse to study impaired detrusor contractility and disrupted muscarinic activity in the aging bladder. Urology 2007;69:407-411.

55 Gomez-Pinilla PJ, Pozo MJ, Camello PJ: Aging differentially modifies agonist-evoked mouse detrusor contraction and calcium signals. Age (Dordr) 2011;33:81-88.

56 Chi M, Zhou Y, Sopariwala D, Periasamy M: SM2(+/-) male mice are predisposed to develop urinary tract obstruction and hyper contractility of the bladder smooth muscle upon ageing. J Smooth Muscle Res 2011; 47:67-78.

57 Perse M, Injac R, Erman A: Oxidative status and lipofuscin accumulation in urothelial cells of bladder in aging mice. PLoS One 2013;8:e59638.
58 Yoshimura N, Chancellor MB, Andersson KE, Christ GJ: Recent advances in understanding the biology of diabetes-associated bladder complications and novel therapy. BJU Int 2005;95:733-738.

59 Daneshgari F, Liu G, Birder L, Hanna-Mitchell AT, Chacko S: Diabetic bladder dysfunction: current translational knowledge. J Urol 2009;182(Suppl):S18-S26.

60 Gomez CS, Kanagarajah P, Gousse AE: Bladder dysfunction in patients with diabetes. Curr Urol Rep 2011;12:419-426.

61 Golbidi S, Laher I: Bladder dysfunction in diabetes mellitus. Front Pharmacol 2010;1:136.

$62 \mathrm{Ho} \mathrm{CH}$, Tai HC, Yu HJ: Urodynamic findings in female diabetic patients with and without overactive bladder symptoms. Neurourol Urodyn 2010;29:424-427.

63 Liu RT, Chung MS, Lee WC, Chang SW, Huang ST, Yang KD, Chancellor MB, Chuang YC: Prevalence of overactive bladder and associated risk factors in 1359 patients with type 2 diabetes. Urology 2011;78:1040 1045.

64 Yamaguchi C, Sakakibara R, Uchiyama T, Yamamoto T, Ito T, Liu Z, Awa Y, Yamamoto K, Nomura F, Yamanishi T, Hattori T: Overactive bladder in diabetes: a peripheral or central mechanisms ? Neurourol Urodyn 2007;26:807-813.

65 Lee WC, Wu HP, Tai TY, Yu HJ, Chiang PH: Investigation of urodynamic characteristics and bladder sensory function in the early stages of diabetic bladder dysfunction in women with type 2 diabetes. J Urol 2009; 181:198-203.

66 Peters SLM, Schmidt M, Michel MC: Rho kinase: a target for treating urinary bladder dysfunction. Trends Pharmacol Sci 2006; 27:492-497.

67 Gu B, Wu G, Si J, Xu Y, Andersson KE: Improving voiding efficiency in the diabetic rat by a 5 -HT1A serotonin receptor agonist. Neurourol Urodyn 2012;3:168-173.

68 Yenilmez A, Ozcifei M, Aydin Y, Turgut M, Uzuner K, Erkul A: Protective effect of highdose thiamine (B1) on rat detrusor contractility in streptozotosin-induced diabetes mellitus. Acta Diabetol 2006;43:103-108.

69 Wang CC, Nagatomi J, Toosi KK, Yoshimura N, Hsieh JH, Chancellor MB, Sacks MS: Diabetes-induced alternations in biomechanical properties of urinary bladder wall in rats. Urology 2009;73:911-915.

70 Torimoto K, Fraser MO, Hirao Y, de Groat WC, Chancellor MB, Yoshimura N: Urethral dysfunction in diabetic rats. J Urol 2004; 171:1959-1964.

71 Yang Z, Dolber PC, Fraser MO: Diabetic urethropathy compounds the effects of diabetic cystopathy. J Urol 2007;178:2213-2219.

72 Tong YC, Cheng JT, Hsu CT: Alterations of $\mathrm{M}(2)$-muscarinic receptor protein and mRNA expression in the urothelium and muscle layer of the streptozotocin-induced diabetic rat urinary bladder. Neurosci Lett 2006; 406:216-221.
73 Cheng JT, Yu BC, Tong YC: Changes of M3 muscarinic receptor protein and mRNA expressions in the bladder urothelium and muscle layer of streptozotocin-induced diabetic rats. Neurosci Lett 2007;423:1-5.

74 Hanna-Mitchell AT, Ruiz GW, Daneshgari F, Liu G, Apodaca G, Birder LA: Impact of diabetes mellitus on bladder uroepithelial cells. Am J Physiol Regul Integr Comp Physiol 2013;304:R84-93.

75 Stevens LA, Sellers DJ, McKay NG, Chapple CR, Chess-Williams R: Muscarinic receptor function, density and G-protein coupling in the overactive diabetic rat bladder. Auton. Autacoid Pharmacol 2006;26:303-309.

76 Daneshgari F, Liu G, Imrey PB: Time dependent changes in diabetes cystopathy in rats include compensated and decompensated bladder function. J Urol 2006;176:380-386.

77 Nsabimana AM, Ojewole JA: Diabetes mellitus and responses of the urinary bladder to acetylcholine: an in vitro study. J Smooth Muscle Res 2008;44:143-150.

78 Luheshi GN and Zar MA: The effect of streptozotocin-induced diabetes on cholinergic motor transmission in the rat urinary bladder. Br J Pharmacol 1991;103:1657-1662.

79 Munoz A, Smith CP, Boone TB, Somogyi GT: Overactive and underactive bladder dysfunction is reflected by alterations in urothelial ATP and NO release. Neurochem Int 2011:58:295-300.

80 Munoz A, Boone TB, Smith CP, Somogyi GT: Diabetic plasticity of non-adrenergic non -cholinergic and P2X-mediated rat bladder contractions. Brain Res Bull 2013;95:40-45.

81 Gonulalan U, Kosan M, Hafez G, Arıoglu E, Akdemir O, Ozturk B, Gur S, Cetinkaya M: The effect of diabetes mellitus on $\alpha 1$-adrenergic receptor subtypes in the bladder of rats Urology 2012;80:951.e9-16.

82 Kubota Y, Nakahara T, Mitani A, Maruko T, Sakamoto K, Ishii K: Augmentation of rat urinary bladder relaxation mediated by beta1-adrenoceptors in experimental diabetes. Eur J Pharmacol 2003;467:191-195.

83 Chang S, Hypolite JA, DiSanto ME, Changolkar A, Wein AJ, Chacko S: Increased basal phosphorylation of detrusor smooth muscle myosin in alloxan-induced diabetic rabbit is mediated by upregulation of Rho-kinase beta and CPI-17. Am J Physiol Renal Physiol 2006;290:F650-F656.

84 Ismael HN, Mustafa S, Thulesius O: Effect of diabetes on cooling-induced detrusor muscle contraction: mediation via Rho-kinase activation. Urology 2010;75:891-895.

85 Chen W, Jiang C, Jin X, Shen W, Song B, Li $\mathrm{L}$ : Roles of stem cell factor on loss of interstitial cells of Cajal in bladder ofdiabetic rats. Urology 2011;78:1443.e1-6.

86 Vahabi B, McKay NG, Lawson K, Sellers DJ: The role of c-kit-positive interstitial cells in mediating phasic contractions of bladder strips from streptozotocin-induced diabetic rats. BJU Int 2011;107:1480-1487. 
87 Tong YC, Cheng JT: Changes in bladder nerve growth factor and p75NTR genetic expression in streptozotocin-induved diabetic rats. BJU Int 2005;96:1392-1396.

88 Sasaki K, Chancellor MB, Phelan MW, Yokoyama T, Fraser MO, Seki S, Kubo K, Kumon H, Groat WC, Yoshimura N: Diabetic cystopathy correlates with a long-term decrease in nerve growth factor levels in the bladder and lumbosacral dorsal root Ganglia. J Urol 2002;168:1259-1264.

89 Jiang YJ, Gong DX, Liu HB, Yang CM, Sun ZX, Kong CZ: Ability of alpha-lipoic acid to reverse the diabetic cystopathy in a rat model. Acta Pharmacol Sin 2008;29:713-719.

90 Li Y, Shi B, Wang D, Wang P, Laudon V, Zhang J, Liu Y: Nerve growth factor and substance P: expression in a rat model of diabetic bladder. Int Urol Nephrol 2011;43:109-116.

91 Pinna C, Zanardo R, Puglisi L: Prostaglandin-release impairment in the bladder epithelium of streptozotosin-induced diabetic rats. Eur J Pharmacol 2000;388:267-273.

92 Li Y, Sun Y, Zhang Z, Feng X, Meng H, Li S, Zhu Y, Chen S, Wang Y, Wang J, Zhang D, Jiang X, Li N, Shi B: Cannabinoid receptors 1 and 2 are associated with bladder dysfunction in an experimental diabetic rat model. BJU Int 2013;112:E143-E150.

93 Vahabi B, Lawson K, McKay NG, Sellers DJ: Phasic activity of urinary bladder smooth muscle in the streptozotocin-induced diabetic rat: effect of potassium channel modulators. Eur J Pharmacol 2011;660:431-437.

94 Mustafa S: Effect of diabetes on the ion pumps of the bladder. Urology 2013;81:211. e17-21.

95 Li WJ, Shin MK, Oh SJ: Poly (ADP-ribose) polymerase is involved in the development of diabetic cystopathy via regulation of nuclear factor kappa B. Urology 2011;77:1265.e1-8.

96 Mumtaz FH, Lau DH, Siddiqui EJ, Morgan RJ, Thompson CS, Mikhailidis DP: Changes in cholinergic and purinergic neurotransmission in the diabetic rabbit bladder. In Vivo 2006;20:1-4.

97 Canda AE, Aktas S, Turna B, Cinar MG: Does diabetes affect the distribution of interstitial cells and neuronal tissue in the bladder, prostate and urethra ofrabbits? Cent Eur J Med 2010;5:108-114.

98 Mumtaz FH, Sullivan ME, Thompson CS, Dashwood MR, Naseem KM, Bruckdorfer KR, Mikhailidis DP, Morgan RJ: Alterations in the nitric oxide synthase binding sites and non-adrenergic, non-cholinergic mediated smooth muscle relaxation in the diabetic rabbit bladder outlet: possible relevance to the pathogenesis of diabetic cystopathy. J Urol 1999;162:558-566.

99 Pak KJ, Ostrom RS, Matsui M, Ehlert FJ: Impaired M3 and enhanced M2 muscarinic receptor contractile function in a streptozotocin model of mouse diabetic urinary bladder. Naunyn-Schmied Arch Pharmacol 2010; 381:441-454.
100 Pak KJ, Ostrom RS, Matsui M, Ehlert FJ: The M2 -muscarinic receptor inhibits the development of streptozotocin-induced neuropathy in mouse urinary bladder. J Pharmacol Exp Ther 2010;335:239-248.

101 Leiria LO, Mónica FZ, Carvalho FD, Claudino MA, Franco-Penteado CF, Schenka A, Grant AD, De Nucci G, Antunes E: Functional, morphological and molecular characterization of bladder dysfunction in streptozotocin-induced diabetic mice: evidence of a role for L-type voltage-operated $\mathrm{Ca} 2+$ channels. Br J Pharmacol 2011;163:1276-1288.

102 Wang Z, Cheng Z, Cristofaro V, Li J, Xiao X, Gomez P, Ge R, Gong E, Strle K, Sullivan MP, Adam RM, White MF, Olumi AF: Inhibition of TNF- $\alpha$ improves the bladder dysfunction that is associated with type 2 diabetes. Diabetes 2012;61:2134-2145.

103 Sadananda P, Vahabi B, Drake MJ: Bladder Outlet Physiology in the Context of Lower Urinary Tract Dysfunction. Neurourology and Urodynamics 2011;30:708-713.

104 Yande S, Joshi M: Bladder outlet obstruction in women. J Mid-life Health 2011;2:11-17.

105 Mirone V, Imbimbo C, Longo N, Fusco F: The detrusor muscle: An innocent victim of bladder outlet obstruction. Eur Urol 2007;51: 57-66.

106 Yamaguchi O, Aikawa K, Shishido K, Nomiya M: Place of overactive bladder in male lower urinary tract symptoms. World J Urol 2009;27:723-728.

107 Roehrborn C: Benign prostatic hyperplasia and lower urinary tract symptom guidelines. Can Urol Assoc J 2012;6(Suppl 2):S130-132.

108 Bayliss M, Wu C, Newgreen D, Mundy AR, Fry $\mathrm{CH}$ : A quantitative study of atropine-resistant contractile responses in human detrusor smooth muscle, from stable, unstable and obstructed bladders. J Urol 1999;162:18331839.

109 Harvey RA, Skennerton DE, Newgreen D, Fry CR: The contractile potency of adenosine triphosphate and ecto-adenosine triphosphatase activity in guinea-pig detrusor and detrusor from patients with a stable, unstable or obstructed bladder. J Urol 2002;168:12351239.

110 O’Reilly BA, Kosaka AH, Chang TK, Ford AP, Ropert R, McMahon SB: A quantitative analysis of purinoceptor expression in the bladders of patients with symptomatic outlet obstruction. BJU Int 2001;87:617-622.

111 Sugaya K, Nishijima S, Kadekawa K, Miyazato M, Mukouyama H: Relationship between lower urinary tract symptoms and urinary ATP in patients with benign prostatic hyperplasia or overactibe bladder. Biomed Res 2009;30:287-294.

112 Kurizaki Y, Ishizuka O, Imamura T, Ishikawa M, Ichino M, Ogawa T, Nishizawa O, Andersson KE: Relationship between expression of $\beta 3$-adrenoceptor mRNA in bladder mucosa and urodynamic findings in men with lower urinary tract symptoms. Neurourol Urodyn 2013;32:88-91.
113 Bouchelouche K, Andersen L, Alvarez S, Nordling J, Bouchelouche P: Increased contractile response to phenylephrine in detrusor of patients with bladder outlet obstruction: effect of the alpha1A and alpha1D-adrenergic receptor antagonist tamsulosin. J Urol 2005; 173:657-661.

114 Kurizaki Y, Ishizuka O, Imamura T, Ichino M, Ogawa T, Igawa Y, Nishizawa O, Andersson KE: Relation between expression of $\alpha(1)$-adrenoceptor mRNAs in bladder mucosa and urodynamic findings in men with lower urinary tract symptoms. Scand J Urol Nephrol 2011;45:15-19.

115 Morelli A, Vignozzi L, Filipi S, Vannelli GB, Ambrosini S, Mancina R, Crescioli C, Donati S, Fibbi B, Colli E, Adorini L, Maggi M: BXL-628, a vitamin D receptor agonist effective in benign prostatic hyperplasia treatment, prevents RhoA activation and inhibits RhoA/ Rho-kinase signaling in rat and human bladder. The Prostate 2007;67:234-247.

$116 \mathrm{Du}$ S, Araki I, Kobayashi H, Zakoji H, Sawada N, Takeda M: Differential expression profile of cold (TRPA1) and cool (TRPM8) receptors in human urogenital organs. Urology 2008;72:450-455.

117 Kim JC, Park EY, Hong SH, Seo SI, Park YH, Hwang TK: Changes of urinary nerve growth factor and prostaglandins in male patients with overactive bladder symptom. Int J Urol 2005; 12:875-880.

118 Romih R, Korosec P, Jezernik K, Sedmak B, Trsinar B, Deng FM, Liang FX, Sun TT: Inverse expression of uroplakins and inducible nitric oxide synthase in the urothelium of patients with bladder outlet obstruction. BJU Int 2003;91:507-512.

119 Kim JC: Underlying mechanisms of detrusor overactivity following bladder outlet obstruction. LUTS 2009;1:S15-S17.

120 Yokoyama T, Kumon H, Nagai A: Correlation of urinary nerve growth factor level with pathogenesis of overactive bladder. Neurourol Urodyn 2008;27:417-420.

121 Boopathi E, Gomes CM, Goldfarb R, John M, Srinivasan VG, Alanzi J, Malkowicz SB, Kathuria H, Zderic SA, Wein AJ, Chacko S: Transcriptional repression of Caveolin-1 (CAV1) gene expression by GATA-6 in bladder smooth muscle hypertrophy in mice and human beings. Am J Pathol 2011;178:22362251.

122 Shaw MB, Herndon CD, Cain MP, Rink RC, Kaefer M: A porcine model of bladder outlet obstruction incorporating radio-telemetered cystometry. BJU Int 2007;100:170-174.

123 Sibley GN: The physiological response of the detrusor muscle to experimental bladder outflow obstruction in the pig. Br J Urol 1987;60:332-336.

124 Zderic SA, Chacko S: Alterations in the contractile phenotype of the bladder: lessons for understanding physiological and pathological remodelling of smooth muscle In vivo measures of $\mathrm{pBOO}$ in a rabbit model. J Cell Mol Med 2012;16:203-217. 
125 Calvert RC, Thompson CS, Khan MA, Mikhailidis DP, Morgan RJ, Burnstock G: Alteration in cholinergic and purinergic signaling in a model of the obstructed bladder. J Urol 2001;166:1530-1533.

126 Bing W, Chang S, Hypolite JA, DiSanto ME, Zderic SA, Rolf L, Wein AJ, Chacko S: Obstruction-induced changes in urinary bladder smooth muscle contractility: a role forRho kinase. Am J Physiol Renal Physiol 2003; 285:F990-997.

127 Chacko S, Chang S, Hypolite J, Disanto M, Wein A: Alteration of contractile and regulatory proteins following partial bladder outlet obstruction. Scan J Urol Nephrol Suppl 2004; 215:26-36.

128 Guven A, Onal B, Kalorin C, Whitbeck C, Chichester P, Kogan B, Levin R, Mannikarottu A: Long term partial bladder outlet obstruction induced contractile dysfunction in male rabbits: a role for rho-kinase. Neurourol Urodyn 2007;26:1043-1049.

129 Masick JM, Levin RM, Hass MA: The effect of partial outlet obstruction on prostaglandin generation in the rabbit urinary bladder. Prostaglandins and other Lipid Mediators 2001; 66:211-219.

130 Kibar Y, Irkilata HC, Yaman H, Onguru O, Coguplugil AE, Ergin G, Seyrek M, Yildiz $\mathrm{O}$, Dayanc M: The effect of intravesical acetylsalicylic acid instillation on tissue prostaglandin levels after partial bladder outlet obstruction in rabbits. Neurourol Urodyn 2011;30:1646-1651.

131 Chen HD, Ye XT, Zhang YR, Weng ZL, Li $\mathrm{CD}$ : Effects of sildenafil on bladder compliance and endothelin-1 in rabbit model of partialbladder outlet obstruction. Zhonghua Yi Xue Za Zhi 2012;92:2720-2723.

132 Walker A, Tanner MJ, Husson P, Schuler C, Kogan BA, Buttyan R, Levin RM: Differential expression of vascular endothelial growth factor, and angiopoietin 1 and 2 in functionally divergent experimental rabbit models of bladder hypertrophy. J Urol 2009;181:27902796.

133 Polyák E, Boopathi E, Mohanan S, Deng M, Zderic SA, Wein AJ, Chacko S: Alterations in caveolin expression and ultrastructure after bladder smooth muscle hypertrophy. J Urol 2009; 182:2497-2503.

134 Chang S, Gomes CM, Hypolite JA, Marx J, Alanzi J, Zderic SA, Malkowicz B, Wein AJ, Chacko $\mathrm{S}$ : Detrusor overactivity is associated with downregulation of large-conductance calcium- and voltage-activated potassium channel protein. Am J Physiol Renal Physiol 2010;298:F1416-F1423.

135 Chang S, Hypolite JA, Mohanan S, Zderic SA, Wein AJ, Chacko S: Alteration of the PKC-mediated signaling pathway for smooth muscle contraction in obstruction-induced hypertrophy of the urinary bladder. Lab Invest 2009;89:823-832.

136 Balasteghin KT, Nardo AM, Amaro JL, Padovani CR: Experimental model of bladder instability in rabbits. Int Braz J Urol 2003; 29:62-67.
137 de Jongh R, van Koeveringe GA, van Kerrebroeck PEV, Markerink-van Ittersum M, de Ventre J, Gillespie JI: Alterations to network of NO/cGMP-responsive interstitial cells induced by outlet obstruction in guinea-pig bladder. Cell Tissue Res 2007;330:147-160.

138 de Jongh R, Miriam Dambros, Guido RMM Haenen, Gertjan JM den Hartog, Aalt Bast, Philip EV van Kerrebroeck, Gommert A. van Koeveringe: Partial bladder outlet obstruction reduces the tissue antioxidant capacity and muscle nerve density of the guinea pig bladder. Neurourol Urodynam 2009;28:461-467.

139 Chertin B, Rolle U, Cascio S, Puri P: Alterations in cholinergic and neuropeptide innervation of urinary bladder following partial bladder outlet obstruction. Pediatr Surg Int 2003;19:427-431

140 Shahab N, Kajioka S, Takahashi-Yanaga F, Onimaru M, Matsuda M, Seki N, Naito S: Obstruction enhances rho-kinase pathway and diminishes protein kinase $\mathrm{C}$ pathway in carbachol-induced calcium sensitization in contraction of $\alpha$-toxin permeabilized guinea pig detrusor smooth muscle. Neurourol Urodyn 2012;31:593-599.

$141 \mathrm{Hu}$ J, Ng YK, Chin CM, Ling EA: Effects of l-arginine and $\mathrm{N}(\mathrm{G})$-nitro-l-arginine methyl ester treatments on expression of neuronal nitric oxide synthase in the guinea-pig bladder after partial bladder outlet obstruction. Neuroscience 2008;151:680-691.

142 Grol S, Nile CJ, Martinez-Martinez P, van Koeveringe G, de Wachter S, de Vente J, Gillespie JI: M3 muscarinic receptor-like immunoreactivity in sham operated and obstructed guinea pig bladders. J Urol 2011; 185:1959-1966.

143 Hashimoto T, Nagabukuro, Doi T: Effects of the selective acetycholineesterase inhibitor TAK-802 on the voiding behavior and bladder mass increase in rats with partial bladder outlet obstruction. J Urol 2005;174:11371141.

144 Cho ST, Park EY, Kim JC: Effect of angiotensin II receptor antagonist telmisartan on detrusor overactivity in rats with bladder outlet obstruction. Urology 2012;80:1163.e1-7.

145 Kim JC, Yoo JS, Park EY, Hong SH, Seo S II, Hwang TK: Muscarinic and purinergic receptor expression in urothelium of rats with detrusor overactivity induced by bladder outlet obstruction. BJU Int 2007;101:371-375.

146 Park MG, Park HS, Lee JG, Kim HJ: Changes in awake cystometry and expression of bladder $\beta$-adrenoceptors after partial bladder outlet obstruction in male rats. Int Neurourol J 2010;14:157-163.

147 Füllhase C, Soler R, Westerling-Andersson $\mathrm{K}$, Andersson KE: Beta3-adrenoceptors in the rat sacral spinal cord and their functional relevance in micturition under normal conditions and in a model of partial urethral obstruction. Neurourol Urodyn 2011;30:13821387.
148 Kim JC, Kim DB, Seo S, Park YH, Hwang TK: Nerve growth factor and vanilloid receptor expression, and detrusor instability, after relieving bladder outlet obstruction in rats. BJU Int 2004;94:915-918.

49 Ha US, Park EY, Kim JC: Effect of botulinum toxin on expression of nerve growth factor and transient receptor potential vanilloid 1 in urothelium and detrusor muscle of rats with bladder outlet obstruction-induced detrusor overactivity. Urology 2011;78:721. e1-721.e6.

150 Sakai T, Kasahara KI, Tomita KI, Ikegaki I, Kuriyama H: 5-hydroxytryptamine-induced bladder hyperactivity via 5-HT2A receptor in partialbladder outlet obstruction in rats. Am J Physiol Renal Physiol 2013;304:F10201027.

151 Takahashi N, Shiomi H, Kushida N, Liu F, Ishibashi K, Yanagida T, Shishido K, Aikawa $\mathrm{K}$, Yamaguchi O: Obstruction alters muscarinic receptor-coupled RhoA/Rho-kinase pathway in the urinary bladder of the rat. Neurourol Urodyn 2009;28:257-262.

152 Aikawa K, Sakai T, Ishibashi K, Shiomi H, Sagawa K, Kumagai S, Kataoka M, Akaihata $\mathrm{H}$, Yamaguchi O: Involvement of angiotensin II type 1 receptor on pathological remodeling and dysfunction in obstructed bladder. Int J Urol 2012;19:457-464.

153 Yildirim A, Onol FF, Haklar G, Tarcan T: The role of free radicals and nitric oxide in the ischemia-reperfusion injury mediated by acute bladder outlet obstruction. Int Urol Nephrol 2008;40:71-77.

154 Aydin M, Wang HZ, Zhang X, Chua R, Downing K, Melman A, DiSanto ME: Largeconductance calcium-activated potassium channel activity, as determined by whole-cell patch clamp recording, is decreased in urinary bladder smooth muscle cells from male rats with partial urethral obstruction. BJU Int 2012;110:E402-408.

155 Beamon CR, Mazar C, Salkini MW, Phull HS, Comiter CV: The effect of sildenafil citrate on bladder outlet obstruction: a mouse model. BJU Int 2009; 104:252-256.

156 Lin W, Rahman NA, Lin J, Zhang H, Gou K, Yu W, Zhu D, Li N, Huhtaniemi I, Li X: Molecular mechanisms of bladder outlet obstruction in transgenic male mice overexpressing aromatase (Cyp19a1). Am J Pathol 2011;178:1233-1244.

157 Nicholson TM, Ricke EA, Marker PC, Miano JM, Mayer RD, Timms BG, vom Saal FS, Wood RW, Ricke WA: Testosterone and $17 \beta$-estradiol induce glandular prostatic growth, bladder outlet obstruction, and voiding dysfunction in male mice. Endocrinology 2012;153:5556-5565.

58 Fey TA, Gopalakrishnan M, Strake JG, King LL, Brioni JD, Sullivan JP, Coghlan MJ, Brune ME: Effects of ATP-sensitive K+ channel openers and tolterodine on involuntary bladder contractions in a pig model of partial bladder outlet obstruction. Neurourol Urodyn. 2003;22:147-155. 
159 Milicic I, Buckner SA, Daza A, Coghlan M, Fey TA, Brune ME, Gopalakrishnan M: Pharmacological characterization of urinary bladder smooth muscle contractility following partial bladder outlet obstruction in pigs. Eur J Pharmacol 2006;532:107-114.

160 Lin WY, Li S, Leggett R, Strassner J, Sokol R, Schuler C, Juan YS, Javed Z, Kogan B, Levin RM, Mannikarottu A: Estrogen administration attenuates bladder outlet obstruction induced oxidative stress in the female rabbit. Neurourol Urodyn 2009;28:95-100.

161 Kubota Y, Hashitani H, Shirasawa N, Kojima Y, Sasaki S, Mabuchi Y, Soji T, Suzuki H, Kohri K: Altered distribution of interstitial cells in the guinea pig bladder following bladder outlet obstruction. Neurourol Urodyn 2008; 27:330-340.

162 Wang Y, Fang Q, Lu Y, Song B, Li W, Li L: Effects of mechanical stretch on interstitial cells of Cajal in guinea pig bladder. J Surg Res 2010;164:e213-219.

163 Kaiho Y, Nishiguchi J, Kwon DD, Chancellor MB, Arai Y, Snyder PB, Yoshimura N: The effects of a type 4 phosphodiesterase inhibitor and the muscarinic cholinergic antagonist tolterodine tartrate on detrusor overactivity in female rats with bladder outlet obstruction. BJU Int 2008;101:615-620.

164 Kitta T, Kakizaki H, Tanaka H, Sano H, Furuno T, Mitsui T, Moriya $\mathrm{K}$, Nonomura $\mathrm{K}$ : An $\alpha$-amino-3-hydroxy-5-methyl-4-isoxazolepropionate glutamate-receptor antagonist can inhibit premicturition contractions in rats with bladder outlet obstruction. BJU Int 2007;100:181-186.

165 Kim SO, Oh BS, Chang IY, Song SH, Ahn K, Hwang EC, Oh KJ, Kwon D, Park K: Distribution of interstitial cells of Cajal and expression of nitric oxide synthase after experimental bladder outlet obstruction in a rat model of bladder overactivity. Neurourol Urodyn 2011;30:1639-1645.

166 Jun JH, Kang HJ, Jin MH, Lee HY, Im YJ, Jung HJ, Han SW: Function of the cold receptor (TRPM8) associated with voiding dysfunction in bladder outlet obstruction in rats. Int Neurourol J 2012;16:69-76.

167 Kang YJ, Jin LH, Park CS, Shin HY, Yoon SM, Lee T: Early sequential changes in bladder function after partial bladder outlet obstruction in awake sprague-dawley rats: focus on the decompensated bladder. Korean J Urol 2011;52:835-841.

168 Metcalfe PD, Wang J, Jiao H, Huang Y, Hori K, Moore RB, Tredget EE: Bladder outlet obstruction: progression from inflammation to fibrosis. BJU Int 2010;106:1686-1694.

169 Zeng J, Pan C, Jiang C, Lindström S: Cause of residual urine in bladder outlet obstruction: an experimental study in the rat. J Urol 2012;188:1027-1032.

170 Velasco C, Guarneri L, Testa R: Effects of intravenous and infravesical administration of suramin, terazosin and BMY 7378 on bladder instabitlity in conscious rats with bladder outlet obstruction. BJU Int 2003;92:131-136.
171 Ohatake A, Ukai M, Saitoh C, Sonoda R, Noguchi Y, Okutsu H, Yuyama H, Sato S, Sasamata M, Miyata K: Effect of tamsulosin on spontaneous bladder contraction in conscious rats with bladder outlet obstruction: comparison with effect on intraurethral pressure. Eur J Pharmacol 2006;545:185-191.

172 Hampel C, Dolber PC, Smith MP, Savic SL, Th roff JW, Thor KB, Schwinn DA: Modulation of bladder alpha1-adrenergic receptor subtype expression by bladder outlet obstruction. J Urol 2002;167:1513-1521.

173 Li Y, Xue L, Miao Q, Mao F, Yao L, Yuan J, Qin W, Zhao Y, Sun H, Liu F, Wang H: Expression and electrophysiological characteristics of P2X(3) receptors in interstitial cells of Cajal in rats with partial bladder outlet obstruction. BJU Int 2013;111:843-851.

174 Bravermann AS, Ruggieri MR: Hypertrophy changes the muscarinic receptor subtype mediating bladder contraction from M3 toward M2. Am J Physiol Regul Untegr Comp Physiol 2003;285:R701-R708.

175 Lluel P, Barras M, Palea S: Cholinergic and purinergic contribution to the micturition reflex in conscious rats with long-term bladder outlet obstruction. Neurourol Urodyn 2002; 21:142-153.

176 Pinna C, Sanvito P, Puglisi L: Altered neurogenic and mechanical responses to acetylcholine, ATP, and substance-P in detrusor from rat with outlet obstruction. Life Sci 2006;79: 1301-1306.

177 Banks FCL, Knight GE, Calvert RC, Morgan RJ, Burnstock G: Alterations in purinergic and cholinergic components of contractile responses of isolated detrusor contraction in a rat model of partial bladder outlet obstruction. BJU Int 2005;97:372-378.

178 Murakami S, Yoshida M, Masunaga K, Maeda Y, Ueda S: Changes in acetylcholine release from rat bladder with partial outlet obstruction. BJU Int 2007;101:633-639.

179 Steers WD, Creedon DJ, Tuttle JB: Immunity to nerve growth factor prevents afferent plasticity following urinary bladder hypertrophy. J Urol 1996;155:379-385.

180 Hayashi T, Kondo T, Ishimatsu M, Takeya M, Igata S, Nakamura K, Matsuoka K: Function and expression pattern of TRPM8 in bladder afferent neurons associated with bladder outlet obstruction in rats. Auton Neurosci 2011; 164:27-33.

181 Beppu M, Araki I, Yoshiyama M, Du S, Kobayashi H, Zakoji H, Takeda M: Bladder outlet obstruction induced expression of prostaglandin E2 receptor subtype EP4 in the rat bladder: a possible counteractive mechanism against detrusor overactivity. J Urol 2011; 186:2463-2469.

182 Song YS, Lee HJ, Doo SW, An J, Kim SU: Enhanced angiogenesis and relaxation of bladder as early response to bladder outlet obstruction. Int J Urol 2013;20:116-122.
183 Kim SO, Choi D, Song SH, Ahn KY, Kwon D, Park K, Ryu SB: Effect of detrusor overactivity on the expression of aquaporins and nitric oxide synthase in rat urinary bladder following bladder outlet obstruction. Can Urol Assoc J 2013;7:E268-274.

184 Zvara P, Folsom JB, Kliment J Jr, Dattilio AL, Moravcikova A, Plante MK, Vizzard MA: Increased expression of neuronal nitric oxide synthase in bladder afferent cells in the lumbosacral dorsal root ganglia after chronic bladder outflow obstruction. Brain Res 2004;1002:35-42.

85 Mittra S, Malhotra S, Naruganahalli KS, Chugh A: Role of peripheral 5-HT1A receptors in detrusor over activity associated with partial bladder outlet obstruction in female rats. Eur J Pharmacol 2007;561:189-193.

186 Sakai T, Kasahara K, Tomita K, Ikegaki I, Kuriyama H: 5-Hydroxytryptamine-induced bladder hyperactivity via the 5-HT2A receptor in partial bladder outlet obstruction in rats. Am J Physiol Renal Physiol 2013;304: F1020-1027.

87 Kang JY, Kim EK, Kim KM: Effects of mirodenafil, a phosphodiesterase-5 inhibitor, on female rat bladder in a partial bladder outlet obstruction model: physiological and immunohistochemical aspects. Korean J Urol 2013;54:339-344.

188 Arner A, Sjuve Scott R, Haase H, Morano I, Uvelius B: Intracellular calcium in hypertrophic smooth muscle from rat urinary bladder. Scand J Urol Nephrol 2007;41:270-277.

189 Kita M, Yunoki T, Takimoto K, Miyazato M, Kita K, de Groat WC, Kakizaki H, Yoshimura $\mathrm{N}$ : Effects of bladder outlet obstruction on properties of $\mathrm{Ca} 2+$-activated $\mathrm{K}+$ channels in rat bladder. Am J Physiol Regul Integr Comp Physiol 2010;298:R1310-1319.

190 Imamura M, Negoro H, Kanematsu A, Yamamoto S, Kimura Y, Nagane K, Yamasaki T, Kanatani I, Ito N, Tabata Y, Ogawa O: Basic fibroblast growth factor causes urinary bladder overactivity through gap junction generation in the smooth muscle. Am J Physiol Renal Physiol 2009;297:F46-F54.

191 Tobu S, Noguchi M, Hatada T, Mori K, Matsuo M, Sakai H: Changes in angiotensin II type 1 receptor expression in the rat bladder by bladder outlet obstruction. Urol Int 2012; 89:241-245.

192 Tanaka H, Kakizaki H, Shibata T, Mitsui T, Koyanagi T: Effect of preemptive treatment of capsaicin or resiniferatoxin on the development of pre-micturition contractions after partial urethral obstruction in the rat. J Urol 2003;170:1022-1026.

193 Wu X, Liang Y, Zhang Z, Cao M, Liang W: Downregulation of TWIK-related arachidonic acid-activated $\mathrm{K}+$ channel in the spinal cord of rats after complete bladder outlet obstruction. Int J Urol 2012;19:944-950. 
194 Miyazato M, Sugaya K, Nishijima S, 206 Potter PJ: Disordered control of the urinary Kadekawa K, Oshiro Y, Hokama S, Uchida A, Ogawa Y: Changes of bladder activity and glycine levels in the lumbosacral cord after partial bladder outlet obstruction in rats. Int $\mathrm{J}$ Urol 2008; 15:843-847.

195 Lee T, Hedlund P, Newgreen D, Andersson KE: Urodynamic effects of a novel EP1 receptor antagonist in normal rats and rats with bladder outlet obstruction. J Urol 2007;177: 1562-1567.

196 Pandita RK, Fujiwara M, Alm P, Andersson KE: Cystometric evaluation of bladder function in non-anesthetized mice with and without bladder outlet obstruction. J Urol 2000; 164:1385-1389.

197 Schröder A, Uvelius B, Newgreen D, Andersson KE: Bladder overactivity in mice after 1 week of outlet obstruction. Mainly afferent dysfunction? J Urol 2003;170:1017-1021.

198 Boberg L, Poljakovic M, Rahman A, Eccles $\mathrm{R}$, Arner A: Role of Rho-kinase and protein kinase $\mathrm{C}$ during contraction of hypertrophic detrusor in mice with partial urinary bladder outlet obstruction. BJU Int 2012;109:132140.

199 Park JM, Yang T, Arend LJ, Schnermann JB, Peters CA, Freeman MR, Briggs JP: Obstruction stimulates COX-2 expression in bladder smooth muscle cells via increased mechanical stretch. Am J Physiol 1999;276:F129F136.

200 Felsen D, Dardashti K, Ostad M, Lemer ML, Gross SS, Chen J, Vaughan ED Jr, Poppas DP: Inducible nitric oxide synthase promotes pathophysiological consequences of experimental bladder outlet obstruction. J Urol 2003;169:1569-1572.

201 Myers JB, Dall'era JE, Koul S, Kumar B, Khandrika L, Flynn BJ, Koul HK: Biochemical alterations in partial bladder outlet obstruction in mice: up-regulation of the mitogen activated protein kinase pathway. J Urol 2009;181:1926-1931.

202 Drzewiecki BA, Anumanthan G, Penn HA, Tanaka ST, Thomas JC, Adams MC, Brock JW 3rd, Pope JC 4th, Matusik RJ,Hayward S, Clayton DB: Modulation of the hypoxic response following partial bladder outlet obstruction. J Urol 2012;188:1549-1554.

203 Baker SA, Hatton WJ, Han J, Hennig GW, Britton FC, Koh SD: Role of TREK-1 potassium channel in bladder overactivity after partial bladder outlet obstruction in mouse. J Urol 2010;183:793-800.

204 Taylor JA, Zhu Q, Irwin B, Maghaydah Y, Tsimikas J, Pilbeam C, Leng L, Bucala R, Kuchel GA: Null mutation in macrophage migration inhibitory factor prevents muscle cell loss and fibrosis in partial bladder outlet obstruction. Am J Physiol Renal Physiol 2006;291:F1343-1353.

205 Schroder A, Newgreen D, Andersson KE: Detrusor response to prostaglandin E2 and bladder outlet obstruction in wild type and EP1 receptor knockout mice. J Urol 2004; 172:1166-1170. bladder after human spinal cord injury: what are the problems? Prog Br Res 2006;152:5157.

207 de Groat WC, Yoshimura N: Plasticity in reflex pathways to the lower urinary tract following spinal cord injury. Exp Neurol 2012; 235:123-132.

208 Cruz CD, Cruz F: Spinal cord injury and bladder dysfunction: new ideas about an old problem. ScientificWorldJournal 2011;11: 214-234.

209 Yoo PB, Horvath EE, Amundsen CL, Webster GD, Grill WM: Multiple pudendal sensory pathways reflexly modulate bladder and urethral activity in patients with spinal cord injury. J Urol 2011;185:737-743.

210 Pontari MA, Braverman AS, Ruggieri MR Sr: The M2 muscarinic receptor mediates in vitro bladder contractions from patients with neurogenic bladder dysfunction. Am J Physiol Regul Integr Comp Physiol 2004;286:R874880.

211 Brady CM, Apostolidis A, Yiangou Y, Baecker PA, Ford AP, Freeman A, Jacques TS, Fowler CJ, Anand P: P2X3-immunoreactive nerve fibres in neurogenic detrusor overactivity and the effect of intravesical resiniferatoxin. Eur Urol 2004;46:247-253.

212 Pannek J, Janek S, Sommerer F, Tannapfel A: Expression of purinergic P2X2-receptors in neurogenic bladder dysfunction due to spinal cord injury: a preliminary immunohistochemical study. Spinal Cord 2009;47:561564.

213 Peng W, Cotrina ML, Han X, Yu H, Bekar L, Blum L, Takano T, Tian GF, Goldman SA, Nedergaard M: Systemic administration of an antagonist of the ATP-sensitive receptor P2X7 improves recovery after spinal cord injury. Proc Natl Acad Sci 2009;106:1248912493.

214 Brady CM, Apostolidis AN, Harper M, Yiangou Y, Beckett A, Jacques TS, Freeman A, Scaravilli F, Fowler CJ, Anand P: Parallel changes in bladder suburothelial vanilloid receptor TRPV1 and pan-neuronal marker PGP9.5 immunoreactivity in patients with neurogenic detrusor overactivity after intravesical resiniferatoxin treatment. BJU Int 2004;93:770-776.

215 Apostolidis A, Brady CM, Yiangos Y, Davis J, Fowler CJ, Anand P: Capsaicin receptor TRPV1 in urothelium of neurogenic human bladders and effect of intravesical resiniferatoxin. Urology 2005;65:400-405.

216 Wall BM, Dmochowski RR, Malecha M, Mangold T, Bobal MA, Cooke CR: Inducible nitric oxide synthase in the bladder of spinal cord injured patients with a chronic indwelling urinary catheter. J Urol 2001;165:14571461 .

217 van Velzen D, Krishnan KR, Parsons KF, Soni BM, Fraser MH, Vaidyanathan S: Epidermal growth factor receptor in the vesical urothelium of paraplegic and tetraplegic patients: an immunohistochemical study. Spinal Cord 1996;34:578-586.
218 Shaker H, Mourad MS, Elbialy MH, Elhilali M: Urinary bladder hyperreflexia: a rat animal model. Neurourol Urodyn 2003;22:693698.

219 Behr-Roussel D, Oger S, Caisey S, Sandner P, Bernabé J, Alexandre L, Giuliano F: Vardenafil decreases bladder afferent nerve activity in unanesthetized, decerebrate, spinal cord-injured rats. Eur Urol 2011;59:272-279.

220 Takahara Y, Maeda M, Nakatani T, Kiyama $\mathrm{H}$ : Transient suppression of the vesicular acetylcholine transporter in urinary bladder pathways following spinal cord injury. $\mathrm{Br}$ Res 2007;1137:20-28.

221 Lee G, Park H, Park HS, Lee JG: Modulation of alpha 1 adrenergic receptors on urinary bladder in rat spinal cord injury model. Int Neurourol J 2012;16:62-68.

222 Bravermann A, Legos J, Young W, Luthin G, Ruggieri M: M2 receptors in genito-urinary smooth muscle physiology. Life Sci 1999; 64:429-436.

223 Matsumoto Y, Miyazato M, Yokoyama H, Kita M, Hirao Y, Chancellor MB, Yoshimura $\mathrm{N}$ : Role of M2 and M3 muscarinic acetylcholine receptor subtypes in activation of bladder afferent pathways in spinal cord injured rats. Urology 2012;79:1184.e15-20.

224 Khera M, Somogyi GT, Kiss S, Boone TB, Smith CP: Botulinum toxin A inhibits ATP release from bladder urothelium after chronic spinal cord injury. Neurochem Int 2004; 45:987-993.

225 Wang X, Arcuino G, Takano T, Lin J, Peng WG, Wan P, Li P, Xu Q, Liu QS, Goldman SA, Nedergaard M: P2X7 receptor inhibition improves recovery after spinal cord injury. Nat Med 2004;10:821-827.

226 Salas NA, Somogyi GT, Gangitano DA, Boone TB, Smith CP: Receptor activated bladder and spinal ATP release in neurally intact and chronic spinal cord injured rats. Neurochem Int 2007;50:345-350.

227 Lu SH, de Groat WC, Lin ATL, Chen KK, Chang LS: Evaluation of purinergic mechanism for the treatment of voiding dysfunction: A study in conscious spinal cord-injured rats. J Chin Med Assoc 2007:70:439-444.

228 Munoz A, Somogyi GT, Boone TB, Ford AP, Smith CP: Modulation of bladder afferent signals in normal and spinal cord-injured rats by purinergic $\mathrm{P} 2 \mathrm{X} 3$ and $\mathrm{P} 2 \mathrm{X} 2 / 3$ receptors. BJU Int. 2012;110:E409-E414.

229 Birder LA: Role of the urothelium in urinary bladder dysfunction following spinal cord injury. Pro Br Res 2006;152:135-146.

230 Ogawa T, Sasatomi K, Hiragata S, Seki S, Nishizawa O, Chermansky CJ, Pflug BR, Chancelor MB, Yoshimura N: Therapeutic effects of endothelin-A receptor antagonist on bladder overactivity in rats with chronic spinal cord injury. Urology 2008;71:341-345.

231 Masunaga K, Yoshida M, Inadome A, Iwashita H, Miyamae K, Ueda S: Prostaglandin E2 release from isolated bladder strips in rats with spinal cord injury. Int J Urol 2006; 13:271-276. 
232 Ikeda Y, Fry C, Hayashi F, Stolz D, Griffiths $\mathrm{D}$, Kanai A: Role of gap junctions in spontaneous activity of the rat bladder. Am J Physiol Renal Physiol 2007;293:F1018-F1025.

233 Seki S, Sasaki K, Fraser MO, Igawa Y, Nishizawa O, Chancellor MB, de Groat WC, Yoshimura N: Immunoneutralization of nerve growth factor in the lumbosacral spinal cord reduces bladder hyperreflexia in spinal cord injured rats. J Urol 2002;168:2269-2274.

234 Forner S, Andrade EL, Martini AC, Bento AF, Medeiros R, Koepp J, Calixto JB: Effects of kinin $\mathrm{B}(1)$ and $\mathrm{B}(2)$ receptor antagonists on overactive urinary bladdersyndrome induced by spinal cord injury in rats. Br J Pharmacol 2012;167:1737-1752.

235 Andrade EL, Forner S, Bento AF, Leite DF, Dias MA, Leal PC, Koepp J, Calixto JB: TRPA1 receptor modulation attenuates bladder overactivity induced by spinal cord injury. Am J Physiol Renal Physiol 2011;300: F1223-F1234.

236 Santos-Silva A, Charrua A, Cruz CD, Gharat L, Avelino A, Cruz F: Rat detrusor overactivity induced by chronic spinalization can be abolished by a transient receptor potential vanilloid 1 (TRPV1) antagonist. Auton Neurosci 2012;166:35-38.

237 Johnston L, Cunningham RM, Young JS, Fry $\mathrm{CH}$, McMurray G, Eccles R, McCloskey KD: Altered distribution of interstitial cells and innervation in the rat urinary bladder following spinal cord injury. J Cell Mol Med 2012; 16:1533-1543.

238 Gan XG, An RH, Bai YF, Zong DB: Expressions of voltage-gated $\mathrm{K}+$ channel 2.1 and 2.2 in rat bladder with detrusor hyperreflexia. Chin Med J 2008;121:1574-1577.

239 Cruz CD, McMahon SB, Cruz F: Spinal ERK activation contributes to the regulation of bladder function in spinal cord injured rats. Exptl Neurol 2006;200:66-73.

240 Zinck ND, Rafuse VF, Downie JW: Sprouting of CGRP primary afferents in lumbosacral spinal cord precedes emergence of bladder activity after spinal injury. Exp Neurol 2007;204:777-790.

241 Zhang X, Douglas KL, Jin H, Eldaif BM, Nassar R, Fraser MO, Dolber PC: Sprouting of substance P-expressing primary afferent central terminals and spinal micturition reflex NK1 receptor dependence after spinal cord injury. Am J Physiol Regul Integr Comp Physiol 2008;295:R2084-R2096.

242 Zhang F, Liao L, Ju Y, Song A, Liu Y: Neurochemical plasticity of nitric oxide synthase isoforms in neurogenic detrusor overactivity after spinal cord injury. Neurochem Res 2011;36:1903-1909.

243 Erschbamer M, Pernold K, Olson L: Inhibiting epidermal growth factor receptor improves structural, locomotor, sensory, and bladder recovery from experimental spinal cord injury. J Neurosci 2007;27:6428-6435.
244 Vizzard MA: Increased expression of spinal cord Fos protein induced by bladder stimulation after spinal cord injury. Am J Physiol Regul Integr Comp Physiol 2000;279:R295R305.

245 Yoshiyama M, de Groat WC: The role of vasoactive intestinal polypeptide and pituitary adenylate cyclase-activating polypeptide in the neural pathways controlling the lower urinary tract. J Mol Neurosci 2008;36:227-240.

246 Smith CP, Somogyi GT, Bird ET, Chancellor MB, Boone TB: Neurogenic bladder model for spinal cord injury: spinal cord microdialysis and chronic urodynamics. Brain Res Brain Res Protoc 2002;9:57-64.

247 Miyazato M, Sasatomi K, Hiragata S, Sugaya K, Chancellor MB, de Groat WC, Yoshimura N: Suppression of detrusor-sphincter dysynergia by GABA-receptor activation in the lumbosacral spinal cord in spinal cord-injured rats. Am J Physiol Regul Integr Comp Physiol 2008;295:R336-R342.

248 Dolber PC, Gu B, Zhang X, Fraser MO, Thor KB, Reiter JP: Activation of the external urethral sphincter central pattern generation by a 5-HT1A receptor agonist in rats with chronic spinal cord injury. Am J Physiol Regul Integr Comp Physiol 2007;292:R1699-R1706.

249 Chang HY, Cheng CL, Chen JJ, de Groat WC: Serotonergic drugs and spinal cord transactions indicate that different spinal circuits are involved in external urethral sphincter activity in rats. Am J Physiol renal Physiol 2007;292:F1044-F1053.

250 Chang HH, Havton LA: Serotonergic 5-HT(1A) receptor agonist (8-OH-DPAT) ameliorates impaired micturition reflexes in a chronic ventral root avulsion model of incomplete cauda equina/conus medullaris injury. Exp Neurol 2013;239:210-217.

251 Cheng CL, Liu JC, Chang SY, Ma CP, de Groat WC: Effect of capsaicin on the micturition reflex in normal and chronic spinal cord-injured cats. Am J Physiol 1999;277: R786-R794.

252 Tai C, Chen M, Shen B, Wang J, Liu H, Roppolo JR, de Groat WC: Plasticity of urinary bladder reflexes evoked by stimulation of pudendal afferent nerves after chronic spinal cord injury in cats. Exp Neurol 2011;228: 109-117.

253 Gu B, Thor KB, Reiter JP, Dolber PC: Effect of 5-hydroxytryptamine 1 serotonin receptor agonists on noxiously stimulated micturition in cats with chronic spinal cord injury. J Urol 2007; 177:2381-2385.

254 Tai C, Miscik CL, Ungerer TD, Roppolo JR, de Groat WC: Suppression of bladder reflex activity in chronic spinal cord injured cats by activation of serotonin 5-HT1A receptors. Exptl Neurol 2006;199:427-437.

255 Hiraizumi Y, Hisamitsu T, Ichikawa S, Fujimaki E: Long term observation of micturition by spinal cord transected rabbits. Physiol Behav 1987;41:331-339.
256 Yokota T, Yamaguchi O: Changes in cholinergic and purinergic neurotransmission in pathologic bladder of chronic spinal rabbit. J Urol 1996;156:1862-1866.

257 Kimura A, Hsu M, Seldin M, Verkman AS, Scharfman HE, Binder DK: Protective role of aquaporin-4 water channels after contusion spinal cord injury. Ann Neurol 2010;67:794801.

258 Natsume O: Detrusor contractility and overactive bladder in patients with cerebrovascular accident. Int J Urol 2008;15:505-510.

259 McKenzie P, Badlani GH: The incidence and etiology of overactive bladder in patients after cerebrovascular accident. Curr Urol Rep 2012;13:402-406.

260 Suzuki M, Ohtake A, Yoshino T, Yuyama H, Hayashi A, Ukai M, Okutsu H, Noguchi Y, Sato S, Sasamata M: Effects of solifenacin succinate (YM905) on detrusor overactivity in conscious cerebral infarcted rats. Eur J Pharmacol 2005;512:61-66.

261 Yotsuyanagi S, Yokoyama O, Komatsu K, Kodama K, Nagasaka Y, Namiki, M: Role of cyclooxygenase-2 in the development of bladder overactivity after cerebral infarction in the rat. J Urol 2005;174:365-369.

262 Maruyama S, Kurosawa S, Takagi Y, Oki T, Noguchi Y, Ukai M, Yuyama H, Ohtake A, Suzuki M, Sasamata M, Yamada S: Urodynamics and bladder muscarinic receptors in rats with cerebral infarction and bladder outlet obstruction. Neurosci Lett 2007;414:8084.

263 Yamamoto G, Soeda F, Shirasaki T, Takahama K: Ameliorating effects of cloperastine on dysfunction of the urinary bladder caused by cerebral infarction in conscious rats. Can J Physiol Pharmacol 2009;87:893-899.

264 Fu D, Ng YK, Gan P, Ling EA: Permanent occlusion of the middle cerebral artery upregulates expression of cytokines and neuronal nitric oxide synthase in the spinal cord and urinary bladder in the adult rat. Neuroscience 2004;125:819-831.

265 Nagasaka Y, Yokoyama O, Komatsu K, Yoshiyuki I, Nakamura Y, Namiki M: Effects of opioid subtypes on detrusor overactivity in rats with cerebral infarction. Int J Urol 2007; 14:226-231.

266 Nishijima S, Sugaya K, Miyazato M, Ashitomi K, Morozumi M, Ogawa Y: Relationship between bladder activity and amino acid levels in the central nervous system in rats with cerebral infarction. Biomed Res 2003;24: 173-180.

267 Nakai M, Akino H, Kaneda T, Matsuta Y, Shiyama R, Tanase K, Ito H, Aoki Y, Oyama N, Miwa Y, Yokoyama O: Acetylcholinesterase inhibitor acting on the brain improves detrusor overactivity caused by cerebral infarction in rats. Neuroscience 2006;142:475-480.

268 Yokoyama O, Yoshiyama M, Namiki M, de Groat, WC: Changes in dopaminergic and glutaminergic excitatory mechanisms of micturition reflex after middle cerebral artery occlusion in conscious rats. Exptl Neurol 2002;173:129-135. 
269 Kanie S, Yokoyama O, Komatsu K, Kodama K, Yotsuyanagi S, Niikura S, Nagasaka Y, Miyamoto KI, Namiki M: GABAergic contribution to rat bladder hyperactivity after middle cerebral artery occlusion. Am J Physiol 2000;279:R1230-R1238.

270 Yokoyama O: Pharmacological and genetic analysis of mechanisms underlying detrusor overactivity in rats. Neurourol Urodyn 2010; 29:107-111.

271 Yeo L, Singh R, Gundeti M, Barua JM, Masood J: Urinary tract dysfunction in Parkinson's disease: a review. Int Urol Nephrol 2012;44:415-424.

272 Campeau L, Soler R, Andersson KE: Bladder dysfunction and Parkinsonism: current pathophysiological understanding and management strategies. Curr Urol Rep 2011;12:396403.

273 Sakakibara R, Tateno F, Kishi M, Tsuyuzaki Y, UchiyamaT, Yamamoto T: Pathophysiology of bladder dysfunction in Parkinson's disease. Neurobiol Dis 2012;46:565-571.

274 Miller IN, Cronin-Golomb A: Gender differences in Parkinson's disease: clinical characteristics and cognition. Mov Disord 2010;25: 2695-703.

275 Duty S, Jenner P: Animal models of Parkinson's disease: a source of novel treatments and clues to the cause of the disease. $\mathrm{Br} \mathrm{J}$ Pharmacol 2011;164:1357-1391.

276 Tamás A, Lubics A, Szalontay L, Lengvári I, Reglodi D: Age and gender differences in behavioral and morphological outcome after 6-hydroxydopamine-induced lesion of the substantia nigra in rats. Behav Brain Res 2005;158:221-229.

277 Yoshimura N, Kuno S, Chancellor MB, de Groat WC Seki S: Dopaminergic mechanisms underlying bladder hyperactivity in rats with a unilateral 6-hydroxydopamine (6OHDA) lesion of the nigrostriatal pathway. Br J Pharmacol 2003;139:1425-1432.

278 Soler R, Füllhase C, Santos C, Andersson KE: Development of bladder dysfunction in a rat model of dopaminergic brain lesion. Neurourol Urodyn 2011;30:188-193.

279 Kitta T, Matsumoto M, Tanaka H, Mitsui T, Yoshioka M, Nonomura K: GABAergic mechanism mediated via $\mathrm{D}$ receptors in the rat periaqueductal gray participates in the micturition reflex: an in vivo microdialysis study. Eur J Neurosci 2008;27:3216-3225.

280 Kitta T, Chancellor MB, de Groat WC, Kuno S, Nonomura K, Yoshimura N: Suppression of bladder overactivity by adenosine A2A receptor antagonist in a rat model of Parkinson disease. J Urol 2012;187:1890-1897.

281 Lensch E, Jost WH: Autonomic disorders in multiple sclerosis. Autoimmune Dis 2011; 2011:803841.

282 Nakipoglu GF, Kaya AZ, Orhan G, Tezen O, Tunc H, Ozgirgin N, Ak F: Urinary dysfunction in multiple sclerosis. J Clin Neurosci 2009; 16:1321-1324.
283 Onal B, Siva A, Buldu I, Demirkesen O, Cetinel B: Voiding dysfunction due to multiple sclerosis: a large scale retrospective analysis. Int Braz J Urol 2009;35:326-333.

284 Radziszewski P, Crayton R, Zaborski J, Członkowska A, Borkowski A, Bossowska A, Majewski M: Multiple sclerosis produces significant changes in urinary bladder innervation which are partially reflected in the lower urinary tract functional status-sensory nerve fibers role in detrusor overactivity. Mult Scler 2009;15:860-868.

285 Gevaert T, De Vos R, Everaerts W, Libbrecht L, Van Der Aa F, van den Oord J, Roskams T, De Ridder D: Characterization of upper lamina propria interstitial cells in bladders from patients with neurogenic detrusor overactivity and bladder pain syndrome. J Cell Mol Med 2011;15:2586-2593.

286 Capasso R, Aviello G, Borrelli F, Romano B Ferro M, Castaldo L, Montanaro V, Altieri V, Izzo AA: Inhibitory effect of standardized cannabis sativa extract and its ingredient cannabidiol on rat and human bladder contractility. Urology 2011;77:1006.e9-1006. e15.

287 Vignes JR, Deloire MS, Petry KG, Nagy F: Characterization and restoration of altered inhibitory and excitatory control of micturition reflex in experimental autoimmune encephalomyelitis in rats. J Physiol 2007;578(Pt 2):439-450.

288 Al-Izki S, Pryce G, Giovannoni G, Baker D: Evaluating potential therapies for bladder dysfunction in a mouse model of multiple sclerosis with high-resolution ultrasonography. Mult Scler 2009;15:795-801.

289 Altuntas CZ, Daneshgari F, Izgi K, Bicer F, Ozer A, Sakalar C, Grimberg KO, Sayin I, Tuohy VK: Connective tissue and its growth factor CTGF distinguish the morphometric and molecular remodeling of the bladder in a model of neurogenic bladder. Am J Physiol Renal Physiol 2012;303:F1363-F1369.

290 Moss HE, Tansey EM, Burnstock G: Abnormalities of responses to autonomic stimulation in the mouse urinary bladder associated with Semliki Forest virus-induced demyelination. J Urol 1989;142:850-854.

291 Grover S, Srivastava A, Lee R, Tewari AK, Te AE: Role of inflammation in bladder function and interstitial cystitis. Ther Adv Urol 2011; 3:19-33.

292 Parsons JK, Kurth K, Sant GR: Epidemiologic issues in interstitial cystitis. Urology 2007;69 (Suppl 4A):5-8.

293 Powell-Boone T, Ness TJ, Cannon R, Lloyd LK, Weigent DA, Fillingim RB: Menstrual cycle affects bladder pain sensation in subjects with interstitial cystitis. J Urol 2005; 174:1832-1836.

294 Palea S, Artibani W, Ostardo E, Trist DG, Pietra C: Evidence of purinergic neurotransmission in human urinary bladder affected by interstitial cystitis. J Urol 1993;150:20072012.
295 Sun Y, Chai TC: Role of purinergic signaling in voiding dysfunction. Curr Bladder Dysfunct Rep 2010;5:219-224.

296 Tempest HV, Dixon AK, Turner WH, Elneil S, Sellers LA, Ferguson DR: P2x2 and P2X3 receptor expression in human bladder urothelium and changes in interstitial cystitis. BJU Int 2004;93:1344-1348.

297 Neuhaus J, Schwalenberg T, Horn LC, Alexander H, Stolzenburg JU: New aspects in the differential diagnosis and therapy of bladder pain syndrome/interstitial cystitis. Adv Urol 2011;2011:639479.

298 Lowe EM, Anand P, Terenghi G, Williams-Chestnut RE, Sinicropi DV, Osborne JL: . Increased nerve growth factor levels in the urinary bladder of women with idiopathic sensory urgency and interstitial cystitis. Br J Urol 1997;79:572-577.

299 Jacobs BL, Smaldone MC, Tyagi V, Philips BJ, Jackman SV, Leng WW, Tyagi P: Increased nerve growth factor in neurogenic overactive bladder and interstitial cystitis patients. Can J Urol 2010;17:4989-4994.

300 Liu HT, Tyagi P, Chancellor MB, Kuo HC: Urinary nerve growth factor but not prostaglandin E2 increases in patients with interstitial cystitis/bladder pain syndrome and detrusor overactivity. BJU Int 2010; 106:1681-1685.

301 Rastogi P, Rickard A, Dorokhov N, Klumpp DJ, McHowat J: Loss of prostaglandin E2 release from immortalized urothelial cells obtained from interstitial cystitis patient bladders. Am J Physiol Renal Physiol 2008;294: F1129-F1135.

302 Marchand JE, Sant GR, Kream RM: Increased expression of substance-P receptor-encoding mRNA in bladder biopsies from patients with interstitial cystitis. Br J Urol 1998;81:224-228.

303 Rosamilia A, Vlements JA, Dwuer PL, Kende M, Campbell DJ: Activation of the kallikrein kinin system in interstitial cystitis. J Urol 1999;162:129-134.

304 Mukerji G, Yiangou Y, Corcoran SL, Selmer IS, Smith GD, Benham CD, Bountra C, Agarwal SK, Anand P: Cool and menthol receptor TRPM8 in human urinary bladder disorders and clinical correlations. BMC Urology 2006;6:6

305 Homma Y, Nomiya A, Tagaya M, Oyama T, Takagaki K, Nishimatsu H, Igawa Y: Increased mRNA expression of genes involved in pronociceptive inflammatory reactions in bladder tissue of interstitial cystitis. J Urol 2013;190:1925-1931.

306 Koskela LR, Thiel T, Ehrén I, De Verdier PJ, Wiklund NP: Localization and expression of inducible nitric oxide synthase in biopsies from patients with interstitial cystitis. J Urol 2008;180:737-741.

307 Logadottir YR, Ehren I, Fall M, Wiklund NP, Peeker R, Hanno PM: Intravesical nitric oxide production discriminates between classic and nonulcer interstitial cystitis. J Urol 2004; 171:1148-1150. 
308 Treutlein G, Dorsch R, Euler KN, Hauck SM, Amann B, Hartmann K, Deeg CA: Novel potential interacting partners of fibronectin in spontaneous animal model of interstitial cystitis. PLoS One 2012;7:e51391.

309 Birder LA, Barrick SR, Roppolo JR, Kanai AJ, de Groat WC, Kiss S, Buffington CA: Feline interstitial cystitis results in mechanical hypersensitivity and altered ATP release from bladder urothelium. Am J Physiol Renal Physiol 2003;285:F423-F429.

310 Birder LA, Ruan HZ, Chopra B, Xiang Z, Barrick S, Buffington CA, Roppolo JR, Ford APDW, de Groat WC, Burnstock G: Alterations in $\mathrm{P} 2 \mathrm{X}$ and $\mathrm{P} 2 \mathrm{Y}$ purinergic receptor expression in urinary bladder from normal cats and cats with interstitial cystitis. Am J Physiol Renal Physiol 2004;287:F1084-F1091.

311 Birder LA, Wolf-Johnston A, Buffington CA, Roppolo JR, de Groat WC, Kanai AJ: Altered inducible nitric oxide synthase expression and nitric oxide production in thebladder of cats with feline interstitial cystitis. J Urol 2005;173:625-629.

312 Aronsson P, Johnsson M, Vesela R, Winder M, Tobin G: Adenosine receptor antagonism suppresses functional and histological inflammatory changes in the rat urinary bladder. Auton Neurosci 2012;171:49-57.

313 Pan F, Liu D, Han XM, Li WC, Pang ZL, Li B, Zhang XP, Xiao YJ, Zeng FQ: Urodynamic investigation of cyclophosphamide-induced overactive bladder in conscious rats. Chin Med J 2012;125:321-325.

314 Kageyama A, Fujino T, Taki Y, Kato Y, Nozawa Y, Ito Y, Yamada S: Alteration of muscarinic and purinergic receptors in urinary bladder of rats with cyclophosphamide-induced interstitial cystitis. Neurosci Lett 2008;436:81-84.

315 Nasrin S, Osano A, Ito Y, Yamada S: Beneficial effects of Gosha-jinki-gan and green tea extract in rats with chemical cystitis. J Pharmacol Sci 2013;122:270-277.

316 Dang K, Lamb K, Cohen M, Bielefeldt K, Gebhart GF: Cyclophosphamide-induced bladder inflammation sensitizes and enhances $\mathrm{P} 2 \mathrm{X}$ receptor function in rat bladder sensory neurons. J Neurophysiol 2008;99:49-59.

317 Jang J, Park EY, Seo SI, Hwang TK, Kim JC: Effects of intravesical instillation of cyclooxygenase- 2 inhibitor on the expression of inducible nitric oxide synthase and nerve growth factor in cyclophosphamide-induced overactive bladder. BJU Int 2006;98:435439.

318 Chopra B, Barrick SR, Meyers S, Beckel JM, Zeidel ML, Ford AP, de Groat WC, Birder LA: Expression and function of bradykinin $\mathrm{B} 1$ and $\mathrm{B} 2$ receptors in normal and inflamed rat urinary bladder urothelium. J Physiol 2005;562:859-871.

319 Kim SE, Shin MS, Kim CJ, Park JH, Chung KJ, Jung H, Kim KH, Lee JH, Ko IG: Effects of tamsulosin on urinary bladder function and neuronal activity in the voiding centers of rats with cyclophosphamide-induced overactive bladder. Int Neurourol J 2012;16:13-22.
320 Zhang QL, Qiao LY: Regulation of IGF-1 but not TGF- $\beta 1$ by NGF in the smooth muscle of the inflamed urinary bladder. Regul Pept 2012;177:73-78.

321 Klinger MB, Dattilio A, Vizzard MA: Expression of cyclooxygenase-2 in urinary bladder in rats with cyclophosphamide-induced cystitis. Am J Physiol Regul Integr Comp Physiol 2007;293:R677-R685.

322 Chuang YC, Yoshimura N, Huang CC, Wu M, Chiang PH, Chancellor MB: Intravesical botulinum toxin A administration inhibits COX2 and EP4 expression and suppresses bladder hyperactivity in cyclophosphamide-induced cystitis in rats. Eur Urol 2009;56:159-166.

323 Meotti FC, Forner S, Lima-Garcia JF, Viana AF, Calixto JB: Antagonism of the transient receptor potential ankyrin 1 (TRPA1) attenuates hyperalgesia and urinary bladder overactivity in cyclophosphamide-induced haemorrhagic cystitis. Chem Biol Interact 2013;203: 440-447.

324 Gonzalez EJ, Girard BM, Vizzard MA: Expression and function of transforming growth factor-beta isoforms and cognate receptors in rat urinary bladder following cyclophosphamide-induced cystitis. Am J Physiol Renal Physiol 2013;305:F1265-1276.

325 Vizzard MA: Alterations in spinal cord Fos protein expression induced by bladder stimulation following cystitis. Am J Physiol Regul Integr Comp Physiol 2000;278:R1027R1039.

326 Wada N, Matsumoto S, Kita M, Watanabe M, Hashizume K, Kakizaki H: Effect of intrathecal administration of E-series prostaglandin 1 receptor antagonist in a cyclophosphamide-induced cystitis rat model. Int J Urol 2013;20:235-240.

327 Tyagi P, Tyagi V, Yoshimura N, Witteemer E, Barclay D, Loughran PA, Zamora R, Vodovotz Y: Gender-based reciprocal expression of transforming growth factor-bland the inducible nitric oxide synthase in a rat model of cyclophosphamide-induced cystitis. J Inflamm 2009;6:23.

328 Martins JP, Silva RB, Coutinho-Silva R, Takiya CM, Battastini AM, Morrone FB, Campos MM: The role of $\mathrm{P} 2 \mathrm{X} 7$ purinergic receptors in inflammatory and nociceptive changes accompanying cyclophosphamide-induced haemorrhagic cystitis in mice. Br J Pharmacol 2012;165:183-196.

329 Matsunami M, Miki T, Nishiura K, Hayashi Y, Okawa Y, Nishikawa H, Sekiguchi F, Kubo L, Ozaki T, Tsujiuchi T, Kawabata A: Involvement of the endogenous hydrogen sulfide/Ca(v) 3.2 T-type Ca2+ channel pathway in cystitis-related bladder pain in mice. Br J 34 Pharmacol 2012;167:917-928.

330 Matsumoto-Miyai K, Yamada E, Yoshizumi M, Kawatani M: The regulation of distention-induced ATP release from urothelium by the adenylyl cyclase-cyclic AMP pathway. Biomed Res 2012;33:153-157.
331 Patra PB, Westfall DP: Potentiation of purinergic neurotransmission in guinea-pig urinary bladder by histamine. J Urol 1994;151: 787-790.

332 Patra PB, Westfall DP: Potentiation by bradykinin and substance-P of purinergic neurotransmission in urinary bladder. J Urol 1996; 156:532-535.

333 Ikeda Y, Nakagawa H, Ohmori-Matsuda K, Hozawa A, Masamune Y, Nishino Y, Kuriyama S, Ohnuma T, Tsuji I, Arai Y: Risk factors for overactive bladder in the elderly population: a community-based study with face-to-face interview. Int J Urol 2011;18: 212-218.

334 Gorman JM: Gender differences in depression and response to psychotropic medication. Gend Med 2006;3:93-109.

335 Zhang C, Hai T, Yu L, Liu S, Li Q, Zhang $\mathrm{X}, \mathrm{Xu} \mathrm{T}$, Wang X: Association between occupational stress and risk of overactive bladder and other lower urinary tract symptoms: a cross-sectional study of female nurses in China. Neurourol Urodyn 2013;32:254-260.

336 Easton WA: Overactive bladder symptoms in women: current concepts in patient management. Can J Urol 2010;17(Suppl 1):12-17.

337 Shaw HA, Burrows LJ: Etiology and treatment of overactive bladder in women. South Med J 2011;104:34-39.

338 Klausner AP, Steers WD: Corticotropin releasing factor: a mediator of emotional influences on bladder function. J Urol 2004;172: 2570-2573.

339 Steers WD, Lee KS: Depression and incontinence. World J Urol 2001;19:351-357.

340 Wood SK, Baez MA, Bhatnagar S, Valentino RJ: Social stress-induced bladder dysfunction: potential role of corticotropin-releasing factor. Am J Physiol Regul Integr Comp Physiol 2009;296:R1671-R1678.

341 Smith AL, Leung J, Kun S, Zhang R, Karagiannides I, Raz S, Lee U, Glovatscka V, Pothoulakis C, Bradesi S, Mayer EA, Rodríguez LV: The effects of acute and chronic psychological stress on bladder function in a rodent model. Urology 2011;78:967.e1-7.

342 Klausner AP, Streng T, Na YG, Raju J, Batts TW, Tuttle JB, Andersson KE, Steers WD: The role of corticotropin releasing factor and its antagonist, astressin, on micturition in the rat. Auton Neurosci 2005;123:26-35.

343 LaBergec J, Malley SE, Zvarova K, Vizzard MA: Expression of cortitropin releasing factor and CRF receptors in micturition pathways after cyclophosphamide induced cystitis. Am J Physiol Regul Integr Comp Physiol 2006;291:R692-R703.

344 Bangasser DA: Sex differences in stress-related receptors: "micro" differences with "macro" implications for mood and anxiety disorders. Biol Sex Differ 2013;4:2.

345 Imamura T, Ishizuka O, Nishizawa O: Cold stress induces lower urinary tract symptoms. Int J Urol 2013;20:661-669. 
346 Merrill L, Malley SE, Vizzard MA: Repeated variate stress (RVS) in male rats induces increased voiding frequency, somatic sensitivity and urinary bladder NGF expression. Am J Physiol Regul Integr Comp Physiol 2013; 305:R147-R156.

347 Lee KS, Na YG, Dean-McKinney T, Klausner AP, Tuttle JB, Steers WD: Alterations in voiding frequency and cystometry in the clomipramine induced model of endogenous depression and reversal with fluoxetine. J Urol 2003;170:2067-2071.

348 Burnstock G: Therapeutic potential of purinergic signaling for diseases of the urinary tract. BJU Int 2011;107:192-204.

349 Rahnama'i MS, van Kerrebroeck PE, de Wachter SG, van Koeveringe GA: The role of prostanoids in urinary bladder physiology. Nat Rev Urol 2012;9:283-290.

350 Seth JH, Sahai A, Khan MS, van der Aa F, de Ridder D, Panicker JN, Dasgupta P, Fowler CJ: Nerve growth factor (NGF): a potential urinary biomarker for overactive bladder syndrome (OAB)? BJU Int 2013;111:372-380.

351 Gur S, Kadowitz PJ, Hellstrom WJ: RhoA/ Rho-kinase as a therapeutic target for the male urogenital tract. J Sex Med 2011;8:675687.

352 McCloskey KD: Bladder interstitial cells: an updated review of current knowledge. Acta Physiol (Oxf). 2013;207:7-15.

353 Avelino A, Charrua A, Frias B, Cruz C, Boudes M, de Ridder D, Cruz F: Transient receptor potential channels in bladder function. Acta Physiol (Oxf). 2013;207:110-122.

354 Brading AF, Brain KL: Ion channel modulators and urinary tract function. Handb Exp Pharmacol 2011;202:375-393.
355 Andersson KE, Wein AJ: Pharmacology of 363 Wang ZY, Wang P, Bjorling DE: Treatment the lower urinary tract: basis for current and future treatments of urinary incontinence. Pharmacol Rev 2004;56:581-631.

356 Ruggieri MR Sr: Cannabinoids: potential 364 Fry CH, Daneshgari F, Thor K, Drake M, Ectargets for bladder dysfunction. Handb Exp Pharmacol 2011;202:425-451.

357 Hedlund P: Cannabinoids and the endocannabinoid system in lower urinary tract function. Neurourol Urodyn 2014;33:46-53.

358 Brady CM, DasGupta R, Dalton C, Wiseman OJ, Berkley KJ, Fowler CJ: An open-label pilot study of cannabis-based extracts for bladder dysfunction in advanced multiple sclerosis. Mult Scler 2004;10:425-433.

359 Freeman RM, Adekanmi O, Waterfield MR, Waterfield AE, Wright D, Zajicek J: The effect of cannabis on urge incontinence in patients with multiple sclerosis: a multicentre, randomised placebo-controlled trial (CAMSLUTS). Int Urogynecol J Pelvic Floor Dysfunct 2006; 17:636-641.

360 Kavia RB, De Ridder D, Constantinescu CS, Stott CG, Fowler CJ: Randomized controlled trial of Sativex to treat detrusor overactivity in multiple sclerosis. Mult Scler 2010;16: 1349-1359.

361 Gratzke C, Streng T, Stief CG, Alroy I, Limberg BJ, Downs TR, Rosenbaum JS, Hedlund $P$, Andersson KE: Cannabinor, a selective cannabinoid-2 receptor agonist, improves bladder emptying in rats with partial urethral obstruction. J Urol 2011;185:731-736.

362 Wang ZY, Wang P, Bjorling DE: Activation of cannabinoid receptor 2 inhibits experimental cystitis. Am J Physiol Regul Integr Comp Physiol 2013;304:R846-R853. with a cannabinoid receptor 2 agonist decreases severity of established cystitis. J Urol 2014; 191: 1153-1158

cles R, Kanai AJ, Birder LA: Animal models and their use in understanding lower urinary tract dysfunction. Neurourol Urodyn 2010; 29:603-608.

365 Parsons BA, Drake MJ: Animal models in overactive bladder research; in: Andersson KE, Michel MC (eds): Urinary Tract, Handbook of Experimental Pharmacology 202. Springer-Verlag, Berlin Heidelberg, 2011, pp16-43. tern in conscious rat. Urologia 2013;80:7073.

367 Patra PB, Jugus MJ, Laping NJ: Sex difference in cystometry of normal and hypertensive conscious rat. Curr Urol 2007;1:84-88.

368 Patra PB: Micturition in normal and hypertensive conscious rat: sex difference in cyclooxygenase inhibition. Curr Urol 2007;1: 134-140.

369 Foon R, Drake MJ: The Overactive bladder Ther Adv Urol 2010;2:147-155.

370 Sellers DJ, Chapple CR, Hay DPW, Chess-Williams R: Depressed contractile responses to neurokinin A in idiopathic but not neurogenic overactive human detrusor muscle. Eur Urol 2006;49:510-518.

371 Fowler CJ: Integrated control of lower urinary tract - clinical perspective. Br J Pharmacol 2006;147:S14-S24.

372 Dmochowski RR: Overactive bladder pharmacotherapy: what does the future hold? BJU Int 2007;99(Suppl 3):13-16.
366 Patra PB: Estrous cycle alters micturition pat- 